

\title{
Sugars and Gastrointestinal Health
}

Djésia Arnone, Caroline Chabot, Anne-Charlotte Heba, Tunay Kökten, Bénédicte Caron, Franck Hansmannel, Natacha Dreumont, Ashwin N Ananthakrishnan, Didier Quilliot, Laurent Peyrin-Biroulet

\section{- To cite this version:}

Djésia Arnone, Caroline Chabot, Anne-Charlotte Heba, Tunay Kökten, Bénédicte Caron, et al.. Sugars and Gastrointestinal Health. 2021. hal-03475394

\section{HAL Id: hal-03475394 \\ https://hal.univ-lorraine.fr/hal-03475394}

Preprint submitted on 21 Dec 2021

HAL is a multi-disciplinary open access archive for the deposit and dissemination of scientific research documents, whether they are published or not. The documents may come from teaching and research institutions in France or abroad, or from public or private research centers.
L'archive ouverte pluridisciplinaire HAL, est destinée au dépôt et à la diffusion de documents scientifiques de niveau recherche, publiés ou non, émanant des établissements d'enseignement et de recherche français ou étrangers, des laboratoires publics ou privés.

\section{(1) (1) $\$$}

Distributed under a Creative Commons Attribution - NonCommercial - NoDerivatives| 4.0 


\section{Journal Pre-proof}

Sugars and Gastrointestinal Health

Djésia Arnone, Caroline Chabot, Anne-Charlotte Heba, Tunay Kökten, Bénédicte Caron, Franck Hansmannel, Natacha Dreumont, Ashwin N. Ananthakrishnan,

Didier Quilliot, Laurent Peyrin-Biroulet

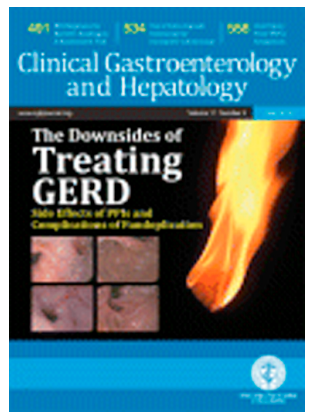

PII:

DOI:

S1542-3565(21)01305-7

Reference:

https://doi.org/10.1016/j.cgh.2021.12.011

YJCGH 58224

To appear in: Clinical Gastroenterology and Hepatology

Accepted Date: 4 December 2021

Please cite this article as: Arnone D, Chabot C, Heba A-C, Kökten T, Caron B, Hansmannel F, Dreumont N, Ananthakrishnan AN, Quilliot D, Peyrin-Biroulet L, Sugars and Gastrointestinal Health, Clinical Gastroenterology and Hepatology (2022), doi: https://doi.org/10.1016/j.cgh.2021.12.011.

This is a PDF file of an article that has undergone enhancements after acceptance, such as the addition of a cover page and metadata, and formatting for readability, but it is not yet the definitive version of record. This version will undergo additional copyediting, typesetting and review before it is published in its final form, but we are providing this version to give early visibility of the article. Please note that, during the production process, errors may be discovered which could affect the content, and all legal disclaimers that apply to the journal pertain.

(C) 2021 by the AGA Institute 


\section{Sugars and Gastrointestinal Health}

Djésia Arnone ${ }^{1,2}$, Caroline Chabot ${ }^{3}$, Anne-Charlotte Heba ${ }^{2}$, Tunay Kökten ${ }^{2}$, Bénédicte Caron ${ }^{4}$, Franck Hansmannel ${ }^{2}$, Natacha Dreumont ${ }^{2}$, Ashwin N Ananthakrishnan ${ }^{5}$, Didier Quilliot ${ }^{2,6}$, Laurent Peyrin-Biroulet ${ }^{2,4}$.

1. CHRU-Nancy, Délégation à la Recherche Clinique et de l'Innovation, Centre Hospitalier Régional Universitaire de Nancy, Nancy, Lorraine, France.

2. Université de Lorraine, Inserm U1256 NGERE « Nutrition - Genetics and exposure to environmental risks », Nancy, France.

3. Université de Lorraine, CHRU-Nancy, Pediatric Hepato-Gastroenterology and Nutrition Unit, Department of Child Medicine and Clinical Genetics, Inserm U1256, Université de Lorraine, F-54000 Nancy, France.

4. Université de Lorraine, CHRU-Nancy, Department of Gastroenterology, F-54000 Nancy, France.

5. Division of Gastroenterology, Massachusetts General Hospital, Boston, Massachusetts.

6. Université de Lorraine, CHRU-Nancy, Department of Diabetology-EndocrinologyNutrition, F-54000 Nancy, France.

\section{Corresponding author:}

Prof. Laurent Peyrin-Biroulet, MD, PhD

Department of Gastroenterology, Nancy University Hospital, University of Lorraine, France.

University of Lorraine, Inserm U1256 NGERE « Nutrition - Genetics and exposure to environmental risks », Vandoeuvre-les-Nancy, France.

Batiment C, 2ème étage

9 avenue de la Forêt de Haye

BP 50184

54505 Vandœuvre-lès-Nancy Cedex

FRANCE

Tel +33383153661

Fax +33383153633

peyrinbiroulet@gmail.com 


\section{Funding and sponsorship}

This work was supported by the Fondation pour la Recherche Médicale (FRM grant number ECO20170637494 to DA) and by the Société Francophone de Nutrition Clinique et Métabolisme (SFNCM research award 2020 to DA).

\section{Declaration of interest}

Laurent Peyrin-Biroulet reports personal fees from AbbVie, Janssen, Genentech, Ferring, Tillots, Pharmacosmos, Celltrion, Takeda, Boerhinger Ingelheim, Pfizer, Index Pharmaceuticals, Sandoz, Celgene, Biogen, Samsung Bioepis, Alma, Sterna, Nestle, Enterome, Allergan, MSD, Roche, Arena, Gilead, Hikma, Amgen, BMS, Vifor, Norgine, Mylan, Lilly, Fresenius Kabi, Oppilan Pharma, Sublimity Therapeutics, Applied Molecular Transport, OSE Immunotherapeutics, Enthera, and Theravance; grants from Abbvie, MSD, and Takeda; and stock options: CTMA. Professor Ashwin N Ananthakrishnan has served as a Scientific Advisory Board member for Abbvie, Gilead, and Kyn Therapeutics and received research grants from Pfizer and Merck. None of the other authors declare any conflicts of interest. 


\section{ABSTRACT}

Sugar overconsumption is linked to a rise in the incidence of noncommunicable diseases such as diabetes, cardiovascular diseases and cancer. This increased incidence is becoming a real public health problem that is more severe than infectious diseases, contributing to 35 million deaths annually. Excessive intake of free sugars can cause many of the same health problems as excessive alcohol consumption. Many recent international recommendations have expressed concerns about sugar consumption in Westernized societies, as current consumption levels represent quantities with no precedent during hominin evolution. In both adults and children, the World Health Organization strongly recommends reducing free sugar intake to less than $10 \%$ of total energy intake and suggests a further reduction to below 5\%. Most studies have focused on the deleterious effects of Western dietary patterns on global health and the intestine. Whereas excessive dietary fat consumption is well studied, the specific impact of sugar is poorly described, while refined sugars represent up to $40 \%$ of caloric intake within industrialized countries. However, high sugar intake is associated with multiple tissue and organ dysfunctions. Both hyperglycemia and excessive sugar intake disrupt the intestinal barrier, thus increasing gut permeability and causing profound gut microbiota dysbiosis, which results in a disturbance in mucosal immunity that enhances infection susceptibility. This review aims to highlight the roles of different types of dietary carbohydrates and the consequences of their excessive intake for intestinal homeostasis.

Keywords: sugars; carbohydrates; gut microbiota; nutrition; intestine; glucose; fructose. 


\section{INTRODUCTION}

Food and nutrition are important factors in maintaining health, and their key role in chronic diseases is well established ${ }^{1}$. The concerned countries are mainly the richest, where diet has been profoundly transformed over the last 50 years. The same trends are now being observed in Asia and Africa. The Western diet (WD) is characterized by increased intake of red and processed meat, saturated fat, high-fat dairy products, eggs, refined grains, white potatoes, and high-sugar drinks ${ }^{2-4}$. Fast food, processed food and ultraprocessed food (UPF) are now extensively consumed, while the consumption of fresh fruits and vegetables has decreased ${ }^{3}$. The first consequence of excess caloric intake (without sufficient energy expenditure) is overweight, which is also associated with numerous diseases, such as metabolic and cardiovascular diseases, diabetes ${ }^{5}$, musculo-articular disorders, and some cancers, such as colorectal cancer $(\mathrm{CRC})^{6}$. It is becoming increasingly clear that the dietary habits of modern societies on the one hand and a high body mass index on the other hand constitute risk factors for autoimmune diseases as well as obesity and inflammatory states ${ }^{7}$. Regardless of obesity, this "junk food" phenomenon underlies other chronic pathologies, such as nonalcoholic steatohepatitis and other inflammatory diseases ${ }^{8}$. Many recent recommendations concern sugars because population-wide sugar intake in Westernized societies represents quantities with no precedent during hominin evolution ${ }^{2,9,10}$. Excessive consumption of sugars has been linked with poor oral health, obesity, cardiovascular disorders, metabolic syndrome, and chronic diseases (type II diabetes mellitus, chronic inflammation, cancer, kidney dysfunction, and nonalcoholic fatty liver disease $)^{11-14}$. At the intestinal level, sugars and hyperglycemia strongly affect the gut microbiota and the intestinal barrier by increasing permeability and sensitivity to infections, and they seem to be aggravating factors for $\mathrm{CRC}^{15-18}$. Given the ongoing controversies related to sugar in the diet, a symposium entitled "Sugars and Health Controversies: What Does the Science Say?" was held in 2014 during the American Society for Nutrition Scientific Sessions annual meeting and concluded that more research trials are needed in many areas regarding sugar consumption and health ${ }^{19}$. For a long time, the WD has been implicated in triggering intestinal inflammation, focusing on the specific role of a high-fat diet on intestinal homeostasis, while a high-sugar diet has been poorly studied. Here, we reviewed the different dietary sugar types, their metabolism and the effects of excessive intake on intestinal homeostasis, the gut microbiota, and gastrointestinal diseases.

\section{LITERATURE SEARCH STRATEGY}

See supplementary text. 


\section{SUGAR IN THE WESTERN DIET: A PUBLIC HEALTH PROBLEM}

Considering structural and property differences, dietary carbohydrates can be classified into nondigestible carbohydrates (such as fibers) and digestible carbohydrates ${ }^{20}$ (sucrose, lactose, and some starch), which ae converted into monosaccharides ${ }^{21}$. According to the World Health Organization (WHO), the term "free sugars" refers to all monosaccharides and disaccharides added to foods by the manufacturer, cook or consumer, plus the sugars naturally present in honey, syrups and fruit juices ${ }^{22}$. When analyzing unhealthy elements of the WD and UPF, refined carbohydrates, particularly added sugar and processed grains (such as white flour or white bread), are elements to be considered in the negative effect on the intestine and immune system $^{23}$.

In humans, total carbohydrate intake represents approximately 50-55\% of total nutrient intake in a balanced diet ${ }^{22}$. Eating habits have increased the respective share of sugars and fats ${ }^{24}$. In Europe, 10 years ago, the respective share of carbohydrates in the total caloric availability was approximately $45-55 \%$. In both adults and children, the WHO strongly recommends reducing the intake of free sugars to less than $10 \%$ of the total energy intake and suggests a further reduction in the intake of free sugars to below $5 \%$ of the total energy intake ${ }^{22,25}$. In addition, all reports recommend limiting the intake of added sugars ${ }^{26}$. The relative proportions of the different types of carbohydrates consumed in Westernized countries are difficult to determine precisely. Even if recent studies use standardized questionnaires, careful documentation of outcomes with common definitions, and contemporary statistical approaches to minimize confounding effects, most nutritional studies have generated a substantial body of evidence that challenges the conventional thinking that fats are harmful. The focus of nutrition research has recently shifted to the potential harms of carbohydrates ${ }^{27}$.

National representative dietary surveys worldwide have shown excessive sugar intake in many Westernized countries (Figure 1) ${ }^{26}$. The prevalence of overconsumption of free sugar has been shown to be high in the UK $(61 \%)$ and in France $(41 \%)^{28}$. Overall, in 2007, the USA global sugar supply was over 600 calories per person per day, between 300-500 calories in Europe and less than 100 calories in central Africa ${ }^{10}$, and added sugar intake was higher in children and adolescents than in adults ${ }^{26,28,29}$. A meta-analysis of longitudinal studies has shown that free sugar intake does not decrease from adolescence to early adulthood ${ }^{30}$. Very early nutritional interventions are therefore necessary (between 13 and 30 years old) ${ }^{30}$.

Free sugar intake increases overall energy intake by increasing the energy density and reduces nutrient density (micronutrients), leading to an unhealthy diet, weight gain, and an increased risk of noncommunicable disease ${ }^{22}$. Thus, excessive free sugar-containing diets are considered 
to have low nutritional quality ${ }^{28}$. Excessive free sugar intake results from the consumption of high-sugar-content drinks, snacks, "ready to consume" food, and UPF ${ }^{12}$, for which numerous studies have shown exponential growth in consumption in industrialized countries (Figure 1) ${ }^{31}$. Indeed, UPF displaces unprocessed or minimally processed foods and freshly prepared meals and represents an important proportion of the total energy intake in many Westernized countries (Figure 1). These products are described as higher in energy, saturated fat, sugar and sodium and lower in nutrients ${ }^{32}$. Particularly in baby/child food, in most food categories, UPFs have higher energy, fat, saturated fat and sugar contents than minimally processed and processed foods ${ }^{33,34}$.

A systematic review ${ }^{35}$ and many studies have reported a negative correlation between added sugar or UPF intake and diet quality ${ }^{36,37}$. Overconsumption of these UPF diets can be explained by low cost, eating location convenience and confusion in reading the product composition ${ }^{38}$. In addition, the sugar addiction phenomenon is not negligible ${ }^{30}$, as the reduction in total fat consumption with low-fat diets leads to excess intake of refined carbohydrates and added sugar $^{39}$. Public health interventions - mainly via nutritional education/counseling - are moderately successful at reducing sugar-sweetened beverage intake and increasing water intake in children ${ }^{40}$. Importantly, it would be beneficial to policy guidance if future dietary surveys employed a uniform way of expressing sugars that is feasible to measure and has public health significance ${ }^{26,41}$.

\section{CARBOHYDRATE METABOLISM}

Carbohydrates are the most important food energy provider among the macronutrients (between $40-80 \%$ of total energy intake). In nutrition research, the role of dietary carbohydrates has been less extensively studied than those of proteins and fats, even though their properties have implications for our overall health ${ }^{\mathbf{4 2}}$. First, carbohydrate terminology and classification depend on their polymerization degree or digestibility (Figure 2$)^{43}$. Some carbohydrates present the same degree of polymerization but different effects, and physicochemical, technological, or functional characteristics influence sugar metabolism (Table 1) ${ }^{44}$. Carbohydrates have a wide range of physiological effects that may be important to health, such as provision of energy, effects on satiety, control of blood glucose levels (insulin metabolism), protein glycosylation, lipid metabolism, bile acid dihydroxylation, fermentation (short-chain fatty acid (SCFA) production, control of colonic epithelial cell function), bowel habits and the gut microbiota ${ }^{45}$.

\section{Digestion of carbohydrates}


Digestible carbohydrates (e.g., sucrose, lactose and some starch) need to be degraded into monosaccharides (glucose, fructose and galactose) to be absorbed in the small intestine ${ }^{21}$. This digestion involves specific enzymes secreted by the pancreas and the intestinal mucosa. Starch and sucrose are degraded by pancreatic amylase, sucrase-isomaltase (small intestine), and maltase-glucoamylase, while lactose is degraded into glucose and galactose by lactase (Figure 3). In most mammals, in contrast with sucrase and maltase activities, lactase activity declines after weaning, a condition known as lactase nonpersistence ${ }^{46}$. Mammalian genomes do not encode most enzymes needed to degrade the structural polysaccharides present in plant material $^{47}$. In particular, fibers are nondigestible carbohydrates: some are part of cell wall components (e.g., cellulose and hemicellulose) or other structural and nonstructural compounds (e.g., resistant starch (RS), inulin, chitin, pectin, $\beta$-glucan, and oligosaccharides) (Table 1) ${ }^{48}$. The contribution of the gut microbiota to carbohydrate degradation is necessary since humans produce only 17 carbohydrate-active enzymes, whereas some bacterial species in the gut have more than 200 carbohydrate-active enzymes ${ }^{49}$.

\section{Carbohydrate absorption}

The human body can metabolize fructose, galactose and glucose and generate energy as a consequence ${ }^{20}$. Monosaccharide absorption from the small intestine occurs via both energycoupled and non-energy-coupled mechanisms ${ }^{20}$. Glucose is a universal energy transport molecule within the body, and it is absorbed by cotransport of sodium ions with glucose via SGLT1, facilitating diffusion via GLUT2 ${ }^{50}$. Fructose is transported into enterocytes by facilitated diffusion with a specific fructose transporter, GLUT5, and passes by facilitated diffusion to the blood capillaries through GLUT2, which has a lower affinity for fructose than GLUT5 ${ }^{51}$. Compared to that of glucose, the intestinal absorption of fructose appears to be relatively limited and is influenced by many factors, especially aging ${ }^{52}$. In rats, absorption can be increased by fructose itself or by a diet rich in saturated fatty acids ${ }^{53}$. People with malabsorption of fructose, i.e., people who absorb fructose poorly, are prone to diarrhea and flatulence. This intestinal clearance of dietary fructose by the small intestine limits the harmful impact of this sugar and may be a general feature of mammalian metabolism ${ }^{54}$. Recent studies indicate that fructose can stimulate de novo palmitate synthesis both in vivo and in vitro ${ }^{55}$. Moreover, the small intestine converts fructose into glucose and organic acids ${ }^{54}$; research has shown that monosaccharides can not only modulate de novo lipogenic pathways but also be used as a substrate for the synthesis of triglycerides and exported in lipoproteins ${ }^{55}$. Therefore, 
chronic fructose overfeeding is linked to alterations in the postprandial lipid profile and decreased hepatic insulin sensitivity, leading to metabolic diseases ${ }^{56}$.

\section{Fate of absorbed sugars}

Glycemia is among the most strictly controlled physiological variables of organismal homeostasis, and the liver plays a critical role in maintaining this homeostasis ${ }^{8}$. Glucose is delivered by the liver in a controlled manner and is absorbed by peripheral tissues according to their needs. In cells, the glycolysis pathway uses glucose to generate adenosine triphosphate (ATP). This synthesis is highly negatively regulated by ATP itself at the first steps of the glycolysis pathway (production of glyceraldehyde-3-phosphate, G3P).

In contrast, fructose and galactose are almost completely cleared from the blood by the liver. Galactose is entirely transformed into glucose-6-phosphate (G6P), a substrate for glycolysis and the glycogenesis pathways. Hepatic fructose metabolism generates G3P, a major glycolysis intermediate, but bypasses the ATP-dependent regulation steps of glycolysis ${ }^{57}$, producing an "unlimited", unregulated source of glycerol-3-phosphate and acetyl-CoA for hepatic lipogenesis. Other tissues, such as white adipose tissue, may metabolize the remaining fructose $e^{58}$.

\section{Fate of nonabsorbed carbohydrates}

Approximately $40 \mathrm{~g}$ of dietary carbohydrates reach the colon daily, escaping digestion by host enzymes $^{47}$. The main categories are RS, nonstarch polysaccharides and oligosaccharides, although some di- and monosaccharides (e.g., sugar alcohols) may also reach the colon ${ }^{59}$. The human gut microbiota is particularly well adapted to perform the degradation of polysaccharides $^{60}$ : 10000 bacterial enzymes implicated in sugar digestion have been identified $^{61}$. While insoluble fibers are weakly or not metabolized and pass through the intestine, resident microbes in the distal small intestine and colon rapidly ferment soluble fibers $^{48,59}$ and produce SCFAs, e.g., acetate, propionate and butyrate. Butyrate is one of the most important metabolites produced through gastrointestinal microbial fermentation and functions as a major energy source for colonocytes by directly affecting their growth and differentiation ${ }^{62}$. Moreover, butyrate has various physiological effects, including enhancement of intestinal barrier function and mucosal immunity ${ }^{63,64}$.

\section{EXCESSIVE SUGAR INTAKE AND INTESTINAL HOMEOSTASIS}

\section{In vitro evidence}


See supplementary text.

\section{Animal studies}

See supplementary text.

\section{Gut microbiota}

See supplementary text.

\section{SUGAR AND HUMAN GASTROINTESTINAL DISEASES}

Since the 1970s, based on observational studies rather than prospective causality, dietary recommendations have focused on reducing saturated fat intake ${ }^{42}$. However, an increasing number of studies in large cohorts of humans and especially a landmark prospective cohort study, named PURE, found that in $>135,000$ participants from 18 countries, nutritive carbohydrates increase human mortality, whereas dietary fat reduces it, indicating the need for a fundamental change in current nutritional guidelines ${ }^{65}$.

Evidence suggests that processed, simple sugars also reduce white blood cell phagocytosis and possibly increase inflammatory cytokine marker levels in the blood ${ }^{66}$. In contrast, fiber consumption seems to protect against inflammation ${ }^{67}$. Subsequently, the accumulation of sugar in the colon increases the osmotic load, as well as the fermentation rate by the colonic microbiota, and promotes abdominal pain and intestinal dysfunctions ${ }^{20,21,68}$.

High sugar intake is associated with multiple tissue and organ dysfunctions ${ }^{69,70}$ and promotes overweight, cardiovascular diseases, type II diabetes (TIID), insulin resistance, and systemic inflammation (Figure 4). Interestingly, excessive intake of fructose can disrupt metabolic processes and impair organ function ${ }^{58,71}$. As we focused here on the intestine, metabolic syndrome and hepatic consequences of high sugar intake are beyond of the scope of this review. Likewise, even though sugar malabsorption (lactose or fructose intolerance) contributes to some gastrointestinal disorders, we will not discuss these diseases, as they are not caused by sugar overconsumption.

Enterocytes in the intestine can produce fatty acids, with both glucose and fructose used as substrates. Compared with glucose, fructose may be a poor substrate for de novo lipogenesis in enterocytes $^{55}$, and fatty acid accumulation might impair intestinal function. Thus, excessive sucrose intake has been recognized as a primary cause of metabolic syndrome, the toxicity resulting from excess fructose rather than sucrose, as fructose undergoes glycation to proteins and, physiologically, its metabolic substrate rapidly flows into de novo lipogenesis, which promotes liver inflammation ${ }^{72}$. Additionally, the pro-oxidative and proinflammatory effects of 
fructose lead to an increase in gut permeability and endotoxemia that exacerbate chronic inflammation $^{18,73}$.

\section{Irritable bowel syndrome}

Irritable bowel syndrome (IBS) is a functional bowel disorder associated with a wide variety of clinical symptoms, and soluble fiber appears to improve IBS symptoms. There is no evidence for recommending insoluble fiber for $\mathrm{IBS}^{74}$. A low-fermentable oligosaccharides, disaccharides, monosaccharides and polyols (FODMAPs) diet is a possible therapy for IBS ${ }^{75}$. A recent meta-analysis showed that lactose intolerance is more frequent in IBS patients but failed to prove the association of IBS with lactose maldigestion due to the lack of statistical power ${ }^{76}$. Few recent studies have attempted to elucidate the mechanisms by which fermentable carbohydrates may trigger IBS symptoms ${ }^{77}$.

\section{Inflammatory bowel diseases}

Inflammatory bowel diseases (IBDs), including Crohn's disease (CD) and ulcerative colitis (UC), are chronic inflammatory diseases of the gastrointestinal tract with increasing incidence worldwide $^{78,79}$, especially in the pediatric population ${ }^{80}$. Many studies have been conducted to identify environmental factors triggering or exacerbating $\operatorname{IBD}^{81}$. Notably, different epidemiological data have suggested that the consumption of a WD is associated with increased IBD risk ${ }^{4}$. Moreover, overweight and obesity are clearly defined as risk factors for IBD aggravation $^{82,83}$. In the European Prospective Investigation into Cancer and Nutrition (EPIC) cohort, consumers of high levels of sugar and soft drinks were at higher UC risk if they had low vegetable intake ${ }^{84}$. Moreover, in retrospective studies, patients with $C D$ showed an increased consumption of monosaccharides prior to feeling ill ${ }^{85,86}$. Accordingly, a recent prospective cohort study reported that a higher intake of UPF was positively associated with an increased risk of $\mathrm{IBD}^{87}$. Considering the critical role of UPF in IBD and colitis, fructose might have the same effect in the intestine as in the liver ${ }^{88}$.

IBD patients have reported that their perception of the disease manifestation is related to their dietary intake, and they often employ an elimination diet to prevent disease exacerbation ${ }^{89,90}$. In addition to the deleterious effect of sugar described above, the presence of enteral glucose protects the gut epithelium in ischemic conditions ${ }^{91}$. In particular, soda was considered to worsen symptoms. Exclusion of some specific carbohydrates in $\operatorname{IBD}^{92}$ (such as the specific carbohydrate diet or IBD anti-inflammatory diet) was associated with an improvement in clinical manifestation, remission and mucosal healing ${ }^{93}$. 
However, while evidence of varying quality has identified potential harmful or beneficial dietary components, physicians and patients do not currently have guidance as to which foods are safe or may be protective or harmful for $\mathrm{IBD}^{94}$. According to the International Organization for the Study of IBD, evidence is insufficient to recommend any specific changes in refined sugar or complex carbohydrate intake ${ }^{94}$.

\section{Colorectal cancer}

Evidence suggests a positive association between sugar intake and CRC outcomes ${ }^{95}$. In particular, high fructose intake and obesity have been found to be associated with the prevalence of CRC and its progression ${ }^{96}$. Higher sugar-sweetened beverage intake has been shown to be associated with a significantly increased risk of cancer recurrence and mortality in stage III colon cancer patients ${ }^{96}$. Indeed, higher postdiagnosis total fructose and glucose intake has been found to be associated with higher all-cause mortality in stage I-to-III CRC patients ${ }^{97}$. Experimental studies suggest that advanced glycation end products (AGEs) may promote CRC, but prospective epidemiologic studies are inconclusive ${ }^{98}$. Further insight into the metabolism of AGEs and their dicarbonyl precursors and their roles in CRC development is needed ${ }^{98}$.

\section{CONCLUSION}

Despite an ongoing focus on the role of diet in promoting health and longevity, we have only a limited understanding of the nature and impact of concepts at the cellular and molecular levels. In recent decades, there has been a dramatic change in the way people eat and drink, contributing to the increase in the incidence of several noncommunicable diseases ${ }^{9,10,22,24}$. Many recent international recommendations have expressed concerns about sugar consumption in Westernized societies, as they the quantities have no precedent during hominin evolution ${ }^{10,24}$. UPF consumption leads to excessive sugar intake. Sugar metabolism can be divided into two main parts: digestible carbohydrates used as fuel or stored and poorly absorbed carbohydrates, of which some are used by the gut microbiota ${ }^{44}$. Like all nutrients, excessive intake results in accumulation. Because humans have an innate preference for sugar, limiting consumption will not be easy, despite the documented health problems associated ${ }^{99}$. The perception of lipids as "fats!" has been very negative in recent decades, with demonization and drastic avoidance recommendations. This focus seems to turn now to carbohydrates, in particular sugars. In both adults and children, the WHO strongly recommends reducing the intake of free sugars to less than $10 \%$ of total energy intake and suggests a further reduction in the consumption of free sugars to below $5 \%$ of total energy intake ${ }^{10,22,24}$. Despite the growing interest of the scientific and medical community, the direct effects of sugars on healthy individuals' intestines remain 
poorly described ${ }^{19}$. For this reason, an increased focus on the overall effects and quality of carbohydrate sources and meals for food-based guidelines rather than individual componentbased recommendations is needed ${ }^{44}$. However, a recent article suggests that carbohydrate quality seems to have a more important role in population health than carbohydrate amount ${ }^{45}$. Specific effects of sugar (separately from other nutrients (high fat, high sodium, emulsifiers, etc.)) remain difficult to interpret based on available evidence, highlighting the need for experimental studies looking at the individual contributions of each food ${ }^{100}$. Hopefully, continued work in this area will lead to a science-based approach based on high levels of evidence from randomized controlled trials and meta-analyses. This approach can only improve public health and guide wise public policy as well as inform individual nutritional decisions ${ }^{19}$.

\section{FIGURE LEGENDS}

Figure 1: Ultraprocessed food intake seems to lead to sugar overconsumption. Data on total volume sales of ultraprocessed food (UPF) per capita were sourced from the Euromonitor International Passport Global Market Information Database for 80 countries for $2016^{\mathbf{3 4}}$. Data on sugar (raw equivalent) supply were sourced from the Food and Agriculture Organization (FAO) of the United Nations (FAO 2017).

Figure 2: Classification of carbohydrates based on the degree of polymerization and digestibility. Nondigestible carbohydrates are poorly digested by the host ${ }^{\mathbf{4 3}}$. Fermentable oligosaccharides, disaccharides, monosaccharides and polyols (FODMAPs) are responsible for gut symptoms (luminal distension). Prebiotics have putative health benefits (selective growth of bacteria).

Figure 3: Carbohydrate absorption and digestion. Carbohydrate digestion begins in the mouth, where mechanical digestion breaks food into smaller pieces, and salivary amylase (from the parotid and submandibular glands) begins chemical digestion by converting starch into maltose and maltotriose alpha-dextrins (starch fragments). Then, stomach acid halts amylase action. In the small intestine, the breakdown of starch into smaller di- and trisaccharides continues in the lumen of the duodenum and jejunum through the action of pancreatic amylase. The intestinal brush border contains enzymes, including maltase, isomaltase, sucrase, and $\beta$ galactosidase, which degrade carbohydrates into simple sugars. Most simple sugars are then absorbed in the proximal parts of the jejunum via both energy-coupled and non-energy-coupled mechanisms. These transporters are specific small intestine-located protein families (isoforms) of sodium-driven sugar cotransporters (SGLTs) and concentration gradient-dependent glucose 
transporters (GLUTs). Glucose, galactose and fructose are then metabolized in the liver. Other undigested complex polysaccharides then arrive in the colon, where fibrolytic and glycolytic bacteria from the gut microbiota are able to digest cellulose compounds (called xyloglucans) into nutrients - mainly for the bacteria themselves. Other bacteria degrade dietary fiber into short-chain fatty acids (SCFAs) that provide nutrition to cells of the colonic mucosa. SCFAs are the main metabolites produced by the microbiota through the anaerobic fermentation of indigestible polysaccharides such as dietary fibers and resistant starch. They are absorbed by colonocytes, mainly via $\mathrm{H}^{+}$-dependent monocarboxylate transporters (MCTs) or sodiumdependent monocarboxylate transporters (SMCTs). Through binding to G protein-coupled receptors (GPCRs), SCFAs influence intestinal mucosal immunity and barrier integrity and function.

Figure 4: Overview of the consequences of excessive sugar intake. Sugar utilization and metabolism are carefully regulated by the body via a range of mechanisms. Thus, in the case of excessive sucrose intake, compensation mechanisms fail, leading to hyperglycemia, hyperfructosemia and lipogenesis. The latter causes are risk factors for many pathologies, including nonalcoholic fatty liver disease (NAFLD), inflammatory bowel diseases (IBDs), colorectal cancer (CRC), type II diabetes (TIID) and coronary heart disease (CHD).

\section{REFERENCES}

1. Diet, nutrition and the prevention of chronic diseases. World Health Organ Tech Rep Ser 2003;916:i-viii, 1-149, backcover.

2. Barrington WT, Wulfridge P, Wells AE, et al. Improving Metabolic Health Through Precision Dietetics in Mice. Genetics 2018;208:399-417.

3. Myles IA. Fast food fever: reviewing the impacts of the Western diet on immunity. Nutr J 2014;13.

4. Uranga JA, López-Miranda V, Lombó F, et al. Food, nutrients and nutraceuticals affecting the course of inflammatory bowel disease. Pharmacol Rep 2016;68:816-826.

5. Medina-Remón A, Kirwan R, Lamuela-Raventós RM, et al. Dietary patterns and the risk of obesity, type 2 diabetes mellitus, cardiovascular diseases, asthma, and neurodegenerative diseases. Crit Rev Food Sci Nutr 2018;58:262-296.

6. Keku TO, Dulal S, Deveaux A, et al. The gastrointestinal microbiota and colorectal cancer. Am J Physiol Gastrointest Liver Physiol 2015;308:G351-363.

7. Versini M, Jeandel P-Y, Rosenthal E, et al. Obesity in autoimmune diseases: not a passive bystander. Autoimmun Rev 2014;13:981-1000. 
8. Kotas ME, Medzhitov R. Homeostasis, Inflammation, and Disease Susceptibility. Cell 2015;160:816-827.

9. Cordain L, Eaton SB, Sebastian A, et al. Origins and evolution of the Western diet: health implications for the 21st century. Am J Clin Nutr 2005;81:341-354.

10. Lustig RH, Schmidt LA, Brindis CD. Public health: The toxic truth about sugar. Nature 2012;482:27-29.

11. Jensen T, Abdelmalek MF, Sullivan S, et al. Fructose and sugar: A major mediator of non-alcoholic fatty liver disease. J Hepatol 2018;68:1063-1075.

12. Martínez Steele E, Baraldi LG, Louzada ML da C, et al. Ultra-processed foods and added sugars in the US diet: evidence from a nationally representative cross-sectional study. BMJ Open 2016;6:e009892.

13. Martinez-Medina M, Denizot J, Dreux N, et al. Western diet induces dysbiosis with increased E coli in CEABAC10 mice, alters host barrier function favouring AIEC colonisation. Gut 2014;63:116-124.

14. Rohr MW, Narasimhulu CA, Rudeski-Rohr TA, et al. Negative Effects of a High-Fat Diet on Intestinal Permeability: A Review. Adv Nutr Bethesda Md July 2019.

15. Thaiss CA, Levy M, Grosheva I, et al. Hyperglycemia drives intestinal barrier dysfunction and risk for enteric infection. Science 2018;359:1376-1383.

16. Volynets V, Louis S, Pretz D, et al. Intestinal Barrier Function and the Gut Microbiome Are Differentially Affected in Mice Fed a Western-Style Diet or Drinking Water Supplemented with Fructose. J Nutr 2017;147:770-780.

17. Townsend GE, Han W, Schwalm ND, et al. Dietary sugar silences a colonization factor in a mammalian gut symbiont. Proc Natl Acad Sci 2019;116:233-238.

18. Sellmann C, Priebs J, Landmann M, et al. Diets rich in fructose, fat or fructose and fat alter intestinal barrier function and lead to the development of nonalcoholic fatty liver disease over time. J Nutr Biochem 2015;26:1183-1192.

19. Rippe JM, Angelopoulos TJ. Sugars and Health Controversies: What Does the Science Say? Adv Nutr 2015;6:493S-503S.

20. Qi X, Tester RF. Fructose, galactose and glucose - In health and disease. Clin Nutr ESPEN 2019;33:18-28.

21. Omer A, Quigley EMM. Carbohydrate Maldigestion and Malabsorption. Clin Gastroenterol Hepatol Off Clin Pract J Am Gastroenterol Assoc 2018;16:1197-1199.

22. Geneva : World Health Organization. Guideline : Sugars Intake for Adults and Children. Geneva: World Health Organization, 2015. https://public.ebookcentral.proquest.com/choice/publicfullrecord.aspx?p=2033879. Accessed December 1, 2019. 
23. García-Montero C, Fraile-Martínez O, Gómez-Lahoz AM, et al. Nutritional Components in Western Diet Versus Mediterranean Diet at the Gut Microbiota-Immune System Interplay. Implications for Health and Disease. Nutrients 2021;13:699.

24. Evans CEL. Sugars and health: a review of current evidence and future policy. Proc Nutr Soc 2017;76:400-407.

25. Vogel L. Label changes conflict with WHO sugar advice. Can Med Assoc J 2015;187:E186-E186.

26. Newens KJ, Walton J. A review of sugar consumption from nationally representative dietary surveys across the world. J Hum Nutr Diet Off J Br Diet Assoc 2016;29:225-240.

27. Mente A, Yusuf S. Evolving evidence about diet and health. Lancet Public Health 2018;3:e408-e409.

28. Lluch A, Maillot M, Gazan R, et al. Individual Diet Modeling Shows How to Balance the Diet of French Adults with or without Excessive Free Sugar Intakes. Nutrients 2017;9:162.

29. Boulton J, Hashem KM, Jenner KH, et al. How much sugar is hidden in drinks marketed to children? A survey of fruit juices, juice drinks and smoothies. BMJ Open 2016;6:e010330.

30. Winpenny EM, Penney TL, Corder K, et al. Changes in consumption of added sugars from age 13 to 30 years: a systematic review and meta-analysis of longitudinal studies: Change in sugar intake from age 13 to 30 . Obes Rev 2017;18:1336-1349.

31. Hall KD, Ayuketah A, Brychta R, et al. Ultra-Processed Diets Cause Excess Calorie Intake and Weight Gain: An Inpatient Randomized Controlled Trial of Ad Libitum Food Intake. Cell Metab 2019;30:67-77.e3.

32. Elizabeth L, Machado P, Zinöcker M, et al. Ultra-Processed Foods and Health Outcomes: A Narrative Review. Nutrients 2020;12:1955.

33. Grammatikaki E, Wollgast J, Caldeira S. High Levels of Nutrients of Concern in Baby Foods Available in Europe That Contain Sugar-Contributing Ingredients or Are UltraProcessed. Nutrients 2021;13:3105.

34. Vandevijvere S, Jaacks LM, Monteiro CA, et al. Global trends in ultraprocessed food and drink product sales and their association with adult body mass index trajectories. Obes Rev 2019;20:10-19.

35. Louie JCY, Tapsell LC. Association between intake of total vs added sugar on diet quality: a systematic review. Nutr Rev 2015;73:837-857.

36. Afshin A, Sur PJ, Fay KA, et al. Health effects of dietary risks in 195 countries, 19902017: a systematic analysis for the Global Burden of Disease Study 2017. The Lancet 2019;393:1958-1972.

37. Juul F, Simões BDS, Litvak J, et al. Processing level and diet quality of the US grocery cart: is there an association? Public Health Nutr 2019;22:2357-2366. 
38. Laquatra I, Sollid K, Smith Edge M, et al. Including "Added Sugars" on the Nutrition Facts Panel: How Consumers Perceive the Proposed Change. J Acad Nutr Diet 2015;115:1758-1763.

39. Tapsell LC, Neale EP, Satija A, et al. Foods, Nutrients, and Dietary Patterns: Interconnections and Implications for Dietary Guidelines. Adv Nutr 2016;7:445-454.

40. Vargas-Garcia EJ, Evans CEL, Prestwich A, et al. Interventions to reduce consumption of sugar-sweetened beverages or increase water intake: evidence from a systematic review and meta-analysis. Obes Rev Off J Int Assoc Study Obes 2017;18:1350-1363.

41. Tappy L, Morio B, Azzout-Marniche D, et al. French Recommendations for Sugar Intake in Adults: A Novel Approach Chosen by ANSES. Nutrients 2018;10:989.

42. Ravichandran M, Grandl G, Ristow M. Dietary Carbohydrates Impair Healthspan and Promote Mortality. Cell Metab 2017;26:585-587.

43. Cummings JH, Stephen AM. Carbohydrate terminology and classification. Eur J Clin Nutr 2007;61:S5-S18.

44. Brouns F. Saccharide Characteristics and Their Potential Health Effects in Perspective. Front Nutr 2020;7.

45. Ludwig DS, Hu FB, Tappy L, et al. Dietary carbohydrates: role of quality and quantity in chronic disease. The BMJ 2018;361.

46. Kuchay RAH. New insights into the molecular basis of lactase nonpersistence/persistence: a brief review. Drug Discov Ther 2020;14:1-7.

47. Flint HJ, Scott KP, Duncan SH, et al. Microbial degradation of complex carbohydrates in the gut. Gut Microbes 2012;3:289-306.

48. Jha R, Fouhse JM, Tiwari UP, et al. Dietary Fiber and Intestinal Health of Monogastric Animals. Front Vet Sci 2019;6:48.

49. Korpela K. Diet, Microbiota, and Metabolic Health: Trade-Off Between Saccharolytic and Proteolytic Fermentation. Annu Rev Food Sci Technol 2018;9:65-84.

50. Holst JJ, Gribble F, Horowitz M, et al. Roles of the Gut in Glucose Homeostasis. Diabetes Care 2016;39:884-892.

51. Hannou SA, Haslam DE, McKeown NM, et al. Fructose metabolism and metabolic disease. J Clin Invest 2018;128:545-555.

52. Ferraris RP, Choe J-Y, Patel CR. Intestinal Absorption of Fructose. Annu Rev Nutr 2018;38:41-67.

53. Tranchida F, Tchiakpe L, Rakotoniaina Z, et al. Long-term high fructose and saturated fat diet affects plasma fatty acid profile in rats. J Zhejiang Univ Sci B 2012;13:307-317.

54. Jang C, Hui S, Lu W, et al. The Small Intestine Converts Dietary Fructose into Glucose and Organic Acids. Cell Metab 2018;27:351-361.e3. 
55. Hoffman S, Alvares D, Adeli K. Intestinal lipogenesis: how carbs turn on triglyceride production in the gut. Curr Opin Clin Nutr Metab Care 2019;22:284-288.

56. Faeh D, Minehira K, Schwarz J-M, et al. Effect of fructose overfeeding and fish oil administration on hepatic de novo lipogenesis and insulin sensitivity in healthy men. Diabetes 2005;54:1907-1913.

57. Zhang D-M, Jiao R-Q, Kong L-D. High Dietary Fructose: Direct or Indirect Dangerous Factors Disturbing Tissue and Organ Functions. Nutrients 2017;9.

58. Hernández-Díazcouder A, Romero-Nava R, Carbó R, et al. High Fructose Intake and Adipogenesis. Int J Mol Sci 2019;20.

59. Scott KP, Gratz SW, Sheridan PO, et al. The influence of diet on the gut microbiota. Pharmacol Res 2013;69:52-60.

60. Cantarel BL, Lombard V, Henrissat B. Complex Carbohydrate Utilization by the Healthy Human Microbiome. Appanna VD, ed. PLoS ONE 2012;7:e28742.

61. Kaoutari AE, Armougom F, Gordon JI, et al. The abundance and variety of carbohydrateactive enzymes in the human gut microbiota. Nat Rev Microbiol 2013;11:497-504.

62. Campos-Perez W, Martinez-Lopez E. Effects of short chain fatty acids on metabolic and inflammatory processes in human health. Biochim Biophys Acta Mol Cell Biol Lipids 2021;1866:158900.

63. Chambers ES, Preston T, Frost G, et al. Role of Gut Microbiota-Generated Short-Chain Fatty Acids in Metabolic and Cardiovascular Health. Curr Nutr Rep 2018;7:198-206.

64. Fu X, Liu Z, Zhu C, et al. Nondigestible carbohydrates, butyrate, and butyrate-producing bacteria. Crit Rev Food Sci Nutr 2019;59:S130-S152.

65. Dehghan M, Mente A, Zhang X, et al. Associations of fats and carbohydrate intake with cardiovascular disease and mortality in 18 countries from five continents (PURE): a prospective cohort study. Lancet Lond Engl 2017;390:2050-2062.

66. Sørensen LB, Raben A, Stender S, et al. Effect of sucrose on inflammatory markers in overweight humans. Am J Clin Nutr 2005;82:421-427.

67. Llewellyn SR, Britton GJ, Contijoch EJ, et al. Interactions Between Diet and the Intestinal Microbiota Alter Intestinal Permeability and Colitis Severity in Mice. Gastroenterology 2018;154:1037-1046.e2.

68. Lee H-J, Cha J-Y. Recent insights into the role of ChREBP in intestinal fructose absorption and metabolism. BMB Rep 2018;51:429-436.

69. Jegatheesan P, De Bandt J-P. Fructose and NAFLD: The Multifaceted Aspects of Fructose Metabolism. Nutrients 2017;9.

70. Zhang X, Jin Q, Jin LH. High sugar diet disrupts gut homeostasis though JNK and STAT pathways in Drosophila. Biochem Biophys Res Commun 2017;487:910-916. 
71. DiNicolantonio JJ, Mehta V, Onkaramurthy N, et al. Fructose-induced inflammation and increased cortisol: A new mechanism for how sugar induces visceral adiposity. Prog Cardiovasc Dis 2018;61:3-9.

72. Macdonald IA. A review of recent evidence relating to sugars, insulin resistance and diabetes. Eur J Nutr 2016;55:17-23.

73. Do MH, Lee E, Oh M-J, et al. High-Glucose or -Fructose Diet Cause Changes of the Gut Microbiota and Metabolic Disorders in Mice without Body Weight Change. Nutrients $2018 ; 10$.

74. Nagarajan N, Morden A, Bischof D, et al. The role of fiber supplementation in the treatment of irritable bowel syndrome: a systematic review and meta-analysis. Eur J Gastroenterol Hepatol 2015;27:1002-1010.

75. Camilleri M. Diagnosis and Treatment of Irritable Bowel Syndrome: A Review. JAMA 2021;325:865-877.

76. Varjú P, Gede N, Szakács Z, et al. Lactose intolerance but not lactose maldigestion is more frequent in patients with irritable bowel syndrome than in healthy controls: A metaanalysis. Neurogastroenterol Motil Off J Eur Gastrointest Motil Soc 2019;31:e13527.

77. Dimidi E, Rossi M, Whelan K. Irritable bowel syndrome and diet: where are we in 2018 ? Curr Opin Clin Nutr Metab Care 2017;20:456-463.

78. Kaplan GG. The global burden of IBD: from 2015 to 2025. Nat Rev Gastroenterol Hepatol 2015;12:720-727.

79. Ng SC, Shi HY, Hamidi N, et al. Worldwide incidence and prevalence of inflammatory bowel disease in the 21 st century: a systematic review of population-based studies. The Lancet 2017;390:2769-2778.

80. Benchimol EI, Fortinsky KJ, Gozdyra P, et al. Epidemiology of pediatric inflammatory bowel disease: A systematic review of international trends: Inflamm Bowel Dis 2011;17:423-439.

81. Ananthakrishnan AN. Environmental Risk Factors for Inflammatory Bowel Diseases: A Review. Dig Dis Sci 2015;60:290-298.

82. Bilski J, Mazur-Bialy A, Wojcik D, et al. Role of Obesity, Mesenteric Adipose Tissue, and Adipokines in Inflammatory Bowel Diseases. Biomolecules 2019;9:780.

83. Singh S, Dulai PS, Zarrinpar A, et al. Obesity in IBD: epidemiology, pathogenesis, disease course and treatment outcomes. Nat Rev Gastroenterol Hepatol 2017;14:110121.

84. Racine A, Carbonnel F, Chan SSM, et al. Dietary Patterns and Risk of Inflammatory Bowel Disease in Europe: Results from the EPIC Study. Inflamm Bowel Dis 2016;22:345-354.

85. Reif S, Klein I, Lubin F, et al. Pre-illness dietary factors in inflammatory bowel disease. Gut 1997;40:754-760. 
86. Riordan A, Ruxton C, Hunter J. A review of associations between Crohn's disease and consumption of sugars. Eur J Clin Nutr 1998;52:229-238.

87. Narula N, Wong ECL, Dehghan M, et al. Association of ultra-processed food intake with risk of inflammatory bowel disease: prospective cohort study. BMJ July 2021:n1554.

88. Tessitore A, Mastroiaco V, Vetuschi A, et al. Development of hepatocellular cancer induced by long term low fat-high carbohydrate diet in a NAFLD/NASH mouse model. Oncotarget 2017;8:53482-53494.

89. Owczarek D, Rodacki T, Domagała-Rodacka R, et al. Diet and nutritional factors in inflammatory bowel diseases. World J Gastroenterol 2016;22:895-905.

90. Peters V, Tigchelaar-Feenstra EF, Imhann F, et al. Habitual dietary intake of IBD patients differs from population controls: a case-control study. Eur J Nutr April 2020.

91. Huang C-Y, Pai Y-C, Yu LC-H. Glucose-mediated cytoprotection in the gut epithelium under ischemic and hypoxic stress. Histol Histopathol 2017;32:543-550.

92. Gibson PR. Use of the low-FODMAP diet in inflammatory bowel disease. J Gastroenterol Hepatol 2017;32 Suppl 1:40-42.

93. Shivashankar R, Lewis JD. The Role of Diet in Inflammatory Bowel Disease. Curr Gastroenterol Rep 2017;19:22.

94. Levine A, Rhodes JM, Lindsay JO, et al. Dietary Guidance From the International Organization for the Study of Inflammatory Bowel Diseases. Clin Gastroenterol Hepatol 2020;18:1381-1392.

95. Stewart KL, Gigic B, Himbert C, et al. Association of Sugar Intake with Inflammationand Angiogenesis-Related Biomarkers in Newly Diagnosed Colorectal Cancer Patients. Nutr Cancer August 2021:1-8.

96. Fuchs MA, Sato K, Niedzwiecki D, et al. Sugar-sweetened beverage intake and cancer recurrence and survival in CALGB 89803 (Alliance). PloS One 2014;9:e99816.

97. Zoltick ES, Smith-Warner SA, Yuan C, et al. Sugar-sweetened beverage, artificially sweetened beverage and sugar intake and colorectal cancer survival. Br J Cancer July 2021.

98. Aglago EK, Schalkwijk CG, Freisling H, et al. Plasma concentrations of advanced glycation end-products and colorectal cancer risk in the EPIC study. Carcinogenesis March 2021.

99. Di Rienzi SC, Britton RA. Adaptation of the Gut Microbiota to Modern Dietary Sugars and Sweeteners. Adv Nutr 2020;11:616-629.

100. Arnone D, Vallier M, Hergalant S, et al. Long-term overconsumption of fat and sugar causes a partially reversible pre-inflammatory bowel disease state. Front Nutr 2021:33. 
Table 1: Fate and sources of major carbohydrates

\begin{tabular}{|c|c|c|c|c|}
\hline & Molecules & Characteristics & Source & Metabolic Fate \\
\hline Glucose & & $\begin{array}{l}\text { Most abundant } \\
\text { monosaccharide, most } \\
\text { important source of } \\
\text { energy in all } \\
\text { organisms. } \\
\end{array}$ & Fruits, vegetables and honey & $\begin{array}{c}\text { Fuel, stored as glycogen, convert to } \\
\text { other metabolites }\end{array}$ \\
\hline Galactose & & $\begin{array}{l}\text { Sweetness equal to } \\
33 \% \text { of sucrose }\end{array}$ & $\begin{array}{l}\text { Dairy products, avocados, } \\
\text { sugar beets, gums }\end{array}$ & Converted to glucose in liver \\
\hline Fructose & $\mathrm{OH}$ & $\begin{array}{c}\text { In nature, among } \\
\text { sugars, it is the most } \\
\text { sweet, though its } \\
\text { sweetness depends on } \\
\text { the physical state and } \\
\text { the temperature in } \\
\text { which it is. }\end{array}$ & $\begin{array}{l}\text { Fruits (juices), Vegetables and } \\
\text { honey }\end{array}$ & $\begin{array}{c}\text { Partially converted to lactic acid and } \\
\text { glucose } \rightarrow \text { used as fuel or stored as } \\
\text { glycogen and fatty acids used as fuel or } \\
\text { stored as lipid }\end{array}$ \\
\hline Xylose & & $\begin{array}{l}\text { Sweeting power } \\
\text { properties close to } \\
\text { glucose for a lower } \\
\text { caloric intake }\end{array}$ & $\begin{array}{c}\text { Fruits, cereals, bread and } \\
\text { vegetables like potato, peas and } \\
\text { carrots }\end{array}$ & $\begin{array}{l}\text { Poorly metabolized, excreted by } \\
\text { kidneys in the urine }\end{array}$ \\
\hline Arabinose & $\mathrm{OH}$ & $\begin{array}{l}\text { Sweeting power } \\
\text { properties close to } \\
\text { glucose }\end{array}$ & $\begin{array}{l}\text { Plant-based carbohydrate, } \\
\text { commercialized as a sweetener }\end{array}$ & $\begin{array}{l}\text { Uncompetitive inhibitor of sucrase, the } \\
\text { enzyme that breaks down sucrose into } \\
\text { glucose and fructose in the small } \\
\text { intestine }\end{array}$ \\
\hline Sucrose & Glucose $\beta(2 \leftrightarrow 1) \alpha$ fructose & $\begin{array}{l}\text { Ordinary sugar "table } \\
\text { sugar". }\end{array}$ & Produced from cane or beet. & $\begin{array}{l}\text { Digestive enzyme sucrase or isomaltase } \\
\text { glycoside hydrolases in the duodenum } \\
\rightarrow \text { glucose and fructose which are } \\
\text { absorbed and enter the bloodstream }\end{array}$ \\
\hline Isomaltulose & Glucose $\alpha(1 \rightarrow 6)$ fructose & $\begin{array}{c}\text { Provides a natural } \\
\text { sucrose-like sweetness } \\
\text { profile with a } \\
\text { sweetening power }\end{array}$ & $\begin{array}{l}\text { Naturally present in honey and } \\
\text { sugarcane. Industrially } \\
\text { produced from sucrose. }\end{array}$ & $\begin{array}{c}\text { Digestive enzyme isomaltase-sucrase in } \\
\text { the small intestine } \rightarrow \text { glucose and } \\
\text { fructose which are absorbed and enter } \\
\text { the bloodstream }\end{array}$ \\
\hline
\end{tabular}




\begin{tabular}{|c|c|c|c|c|}
\hline & & $\begin{array}{l}\text { about half that of } \\
\text { sucrose }\end{array}$ & & \\
\hline Maltose & Glucose + glucose & $\begin{array}{l}\text { Only about } 30-60 \% \text { as } \\
\text { sweet as sugar, } \\
\text { depending on the } \\
\text { concentration }\end{array}$ & $\begin{array}{l}\text { Obtained from malt, corn syrup } \\
\text { or partially hydrolyzed starch } \\
\text { products like maltodextrin }\end{array}$ & $\begin{array}{c}\text { Digestive enzyme maltase } \rightarrow 2 \text { glucose } \\
\text { which is absorbed and enter the } \\
\text { bloodstream }\end{array}$ \\
\hline Lactose & Glucose + galactose & $\begin{array}{l}\text { mild flavor and easy } \\
\text { handling properties led } \\
\text { to its use as a carrier } \\
\text { and stabilizer of } \\
\text { aromas and } \\
\text { pharmaceutical } \\
\text { products }\end{array}$ & Dairy products & $\begin{array}{l}\text { Digestive enzyme lactase in the small } \\
\text { intestine } \rightarrow \text { glucose and galactose } \\
\text { which are absorbed and enter the } \\
\text { bloodstream. Depending on lactase } \\
\text { activity and ingested dose, undigested } \\
\text { lactose act as dietary fiber. }\end{array}$ \\
\hline Sorbitol & & $\begin{array}{c}\text { Used as sugar } \\
\text { substitute. About } 60 \% \\
\text { as sweet as sucrose. }\end{array}$ & $\begin{array}{l}\text { Sweetener (E420) Made from } \\
\text { potato starch, naturally found } \\
\text { in apples, pears, peaches and } \\
\text { prunes }\end{array}$ & $\begin{array}{l}\text { Poorly absorbed but converted to } \\
\text { glucose and fructose in liver }\end{array}$ \\
\hline Mannitol & (OH & $\begin{array}{c}\text { Used as sugar } \\
\text { substitute and } \\
\text { medication. }\end{array}$ & $\begin{array}{l}\text { Sweetener (E421). Naturally } \\
\text { found in algae and plants. }\end{array}$ & $\begin{array}{l}\text { Poorly absorbed. Increases blood } \\
\text { glucose to a lesser extent than sucrose } \\
\text { (lower glycemic index) }\end{array}$ \\
\hline Xylitol & $Y$ & $\begin{array}{l}\text { Used as sugar } \\
\text { substitute. }\end{array}$ & $\begin{array}{l}\text { Sweetener (E967). Naturally } \\
\text { found in strawberries, } \\
\text { mushrooms and prunes. Made } \\
\text { from birch sap. }\end{array}$ & $\begin{array}{l}\text { About } 50 \% \text { is absorbed, metabolized in } \\
\text { liver in D-xylylose and then goes to } \\
\text { pentose phosphate pathway. } 50 \% \text { non- } \\
\text { absorbed is fermented by gut bacteria } \\
\text { into short-chain acids and gases. at high } \\
\text { doses, may cause gastrointestinal } \\
\text { discomfort. }\end{array}$ \\
\hline
\end{tabular}




\begin{tabular}{|c|c|c|c|c|}
\hline $\begin{array}{l}\text { Fructo- } \\
\text { oligosaccharides } \\
\text { (FOS) }\end{array}$ &  & $\begin{array}{l}\text { Used as an alternative } \\
\text { sweetener and } \\
\text { prebiotics }\end{array}$ & $\begin{array}{l}\text { Naturally found in fruits and } \\
\text { vegetables (sunchoke, bananas, } \\
\text { onions, chicory root, garlic, } \\
\text { asparagus, and leeks). Some } \\
\text { grains and cereals (wheat, } \\
\text { barley). Extracted from blue } \\
\text { agave. }\end{array}$ & $\begin{array}{l}\text { Prebiotic dietary fibres: not hydrolyzed } \\
\text { by salivary and digestive enzymes, } \\
\text { fermented by anaerobic bacteria of the } \\
\text { gut microbiota stimulating the growth of } \\
\text { Bifidobacterica species (produce short- } \\
\text { chain fatty acids and gases) }\end{array}$ \\
\hline $\begin{array}{l}\text { Galacto- } \\
\text { oligosaccharides } \\
\text { (GOS) }\end{array}$ & $\begin{array}{l}\text { Short chains ( } \\
\text { units) of gluco }\end{array}$ & $\begin{array}{l}\text { Available } \\
\text { commercially in food } \\
\text { products for both } \\
\text { infants and adults }\end{array}$ & $\begin{array}{l}\text { Occurring naturally in human } \\
\text { milk can be produced from } \\
\text { lactose by } \beta \text {-galactosidase. }\end{array}$ & $\begin{array}{l}\text { Prebiotic dietary fibres: not hydrolyzed } \\
\text { by salivary and digestive enzymes, } \\
\text { fermented by the gut microbiota } \\
\text { stimulating the growth and/or activity of } \\
\text { beneficial bacteria (bifidobacterial and } \\
\text { lactobacilli species) in the colon } \\
\text { (produce short-chain fatty acids). }\end{array}$ \\
\hline $\begin{array}{c}\text { Xylo- } \\
\text { Oligosaccharides }\end{array}$ & $\begin{array}{r}\text { Oligomers } \\
\mathrm{x}\end{array}$ & $\begin{array}{c}\text { Available } \\
\text { commercially as } \\
\text { prebiotic. }\end{array}$ & $\begin{array}{l}\text { Relatively abundant in cell } \\
\text { walls of grains and plants } \\
\text { (bamboo, shoots, fruits, } \\
\text { vegetables, milk and honey) }\end{array}$ & $\begin{array}{l}\text { Prebiotic dietary fibres: not hydrolyzed } \\
\text { by digestive enzymes, fermented by the } \\
\text { gut microbiota stimulating the growth } \\
\text { and/or activity of beneficial bacteria } \\
\text { (bifidobacterial and lactobacilli species) } \\
\text { in the colon (produce short-chain fatty } \\
\text { acids). }\end{array}$ \\
\hline Inulin & & $\begin{array}{l}\text { Dietary fiber ingredient } \\
\text { used to improve the } \\
\text { nutritional value of } \\
\text { manufactured food } \\
\text { products. }\end{array}$ & $\begin{array}{l}\text { Storage carbohydrates of many } \\
\text { plants' types, traditionally } \\
\text { extracted from chicory but } \\
\text { present in agave, wheat, onion, } \\
\text { bananas, garlic, asparagus, and } \\
\text { Jerusalem artichoke. }\end{array}$ & $\begin{array}{l}\text { Non-digestible oligosaccharide. } \\
\text { Prebiotic dietary fibres: not hydrolyzed } \\
\text { by digestive enzymes, fermented by the } \\
\text { gut microbiota stimulating the growth of } \\
\text { beneficial bacteria. }\end{array}$ \\
\hline Starch & & $\begin{array}{l}\text { Most common } \\
\text { carbohydrate in human } \\
\text { diet. Largely used as an } \\
\text { insoluble dietary fiber } \\
\text { for food processing and } \\
\text { in pharmaceutical } \\
\text { industry. }\end{array}$ & $\begin{array}{l}\text { Major source are cereals (rice, } \\
\text { maize and wheat) or root } \\
\text { vegetables (potatoes) }\end{array}$ & $\begin{array}{l}\text { Poorly digested in the small intestine } \\
\text { (digestibly increased with cooking), } \\
\text { bacterial degradation in the colon. } \\
\text { Resistant starch escapes from digestion } \\
\text { in the small intestine of healthy } \\
\text { individuals } \rightarrow \text { fermented by the gut } \\
\text { microbiota in the colon (produce short- } \\
\text { chain fatty acids). }\end{array}$ \\
\hline
\end{tabular}




\begin{tabular}{|c|c|c|c|c|}
\hline & & & & $\begin{array}{c}\text { Non-resistant starch are hydrolyzed by } \\
\text { salivary and pancreatic amylases } \rightarrow \\
\text { maltose and glucose which are absorbed } \\
\text { and enter the bloodstream } \\
\end{array}$ \\
\hline Cellulose & {$[\underbrace{\mathrm{OH}}_{\mathrm{OH}}]_{\mathrm{OH}^{\mathrm{O}}}^{\mathrm{HO}}$} & & $\begin{array}{c}\text { Most abundant organic } \\
\text { polymer, naturally occurring in } \\
\text { the cell walls of all plants and } \\
\text { algae. }\end{array}$ & $\begin{array}{l}\text { Insoluble dietary fiber, inert to digestive } \\
\text { enzymes. }\end{array}$ \\
\hline Pectins & cono & $\begin{array}{l}\text { Used as gelling, } \\
\text { thickening agent and } \\
\text { stabilizer in food. }\end{array}$ & $\begin{array}{l}\text { Naturally occurring in the cell } \\
\text { walls of fruits and vegetables } \\
\text { (apples, oranges, carrots, citrus } \\
\text { peels, . }\end{array}$ & $\begin{array}{l}\text { Soluble dietary fibern binds to } \\
\text { cholesterol in the gastrointestinal tract } \\
\text { and slows glucose absorption by } \\
\text { trapping carbohydrates. Then, digested } \\
\text { by gut microbiota (Bacteroides } \\
\text { thetaiotaomicron) }\end{array}$ \\
\hline$\beta$-glucans & $\underbrace{\beta-1,3}_{\mathrm{OH}}]_{n}^{\mathrm{O}-1,4}$ & $\begin{array}{l}\text { Used as soluble fiber } \\
\text { supplements. }\end{array}$ & $\begin{array}{c}\text { Naturally occurring in the cell } \\
\text { walls of cereals (oat, barley, } \\
\text { wheat). }\end{array}$ & $\begin{array}{c}\text { Soluble, fermentable fiber acting as a } \\
\text { prebiotic for gut microbiota bacteria. } \\
\text { Enterocytes facilitate the transportation } \\
\text { of } \beta(1,3) \text {-glucans and similar } \\
\text { compounds across the intestinal cell } \\
\text { wall into the lymph, where they interact } \\
\text { with macrophages to activate immune } \\
\text { function. }\end{array}$ \\
\hline Xylans & 然 & $\begin{array}{l}\text { Used as dietary fiber in } \\
\text { bread industry. }\end{array}$ & $\begin{array}{l}\text { Most abundant type of } \\
\text { hemicellulose, naturally } \\
\text { occurring in the vegetal cell } \\
\text { walls. }\end{array}$ & Dietary fibres, porrly absorbed. \\
\hline
\end{tabular}




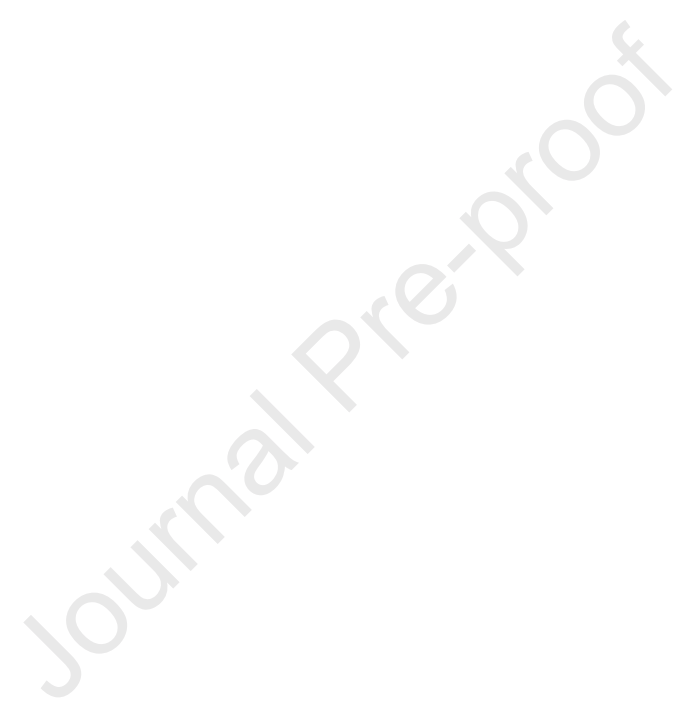




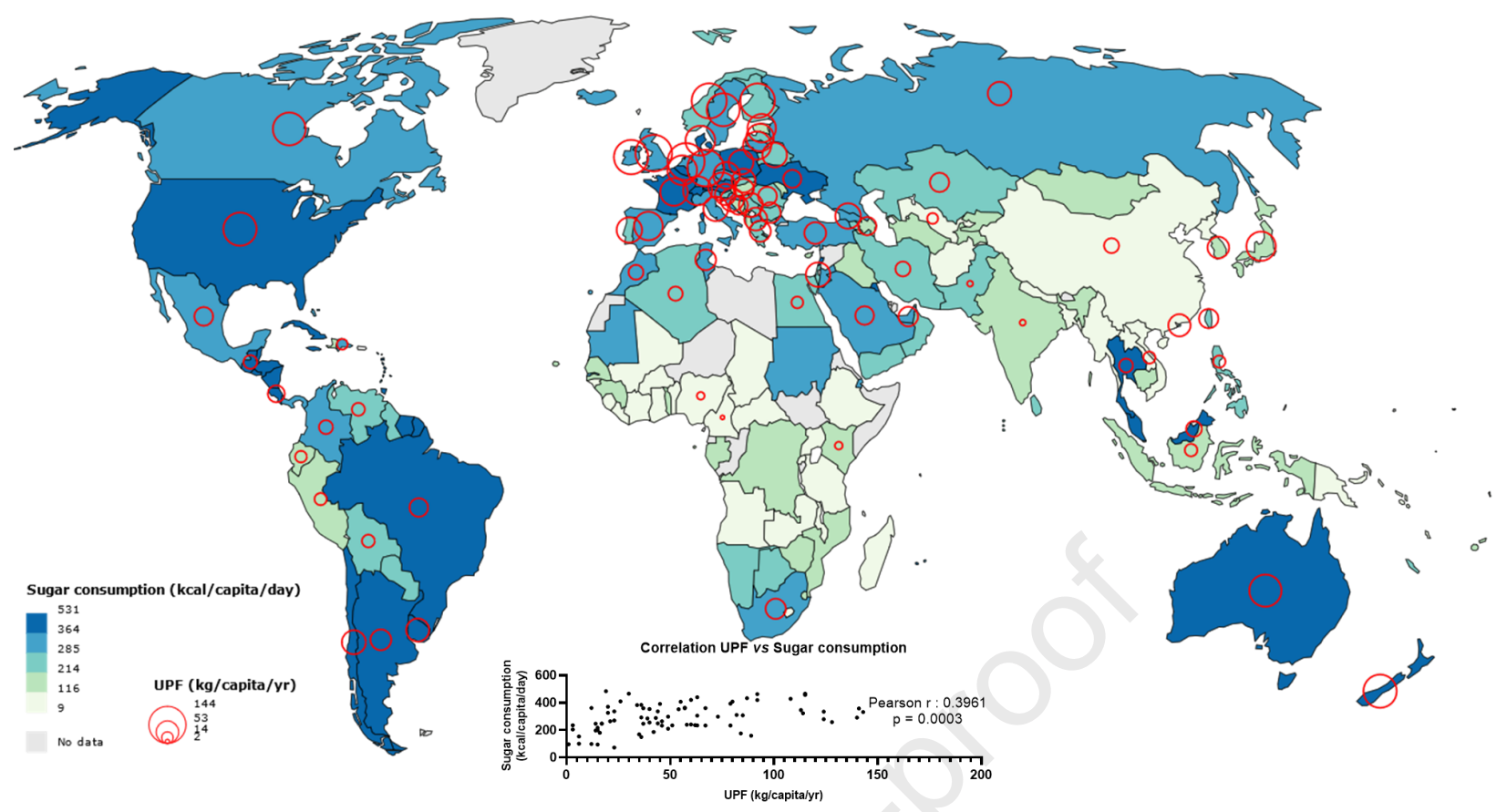




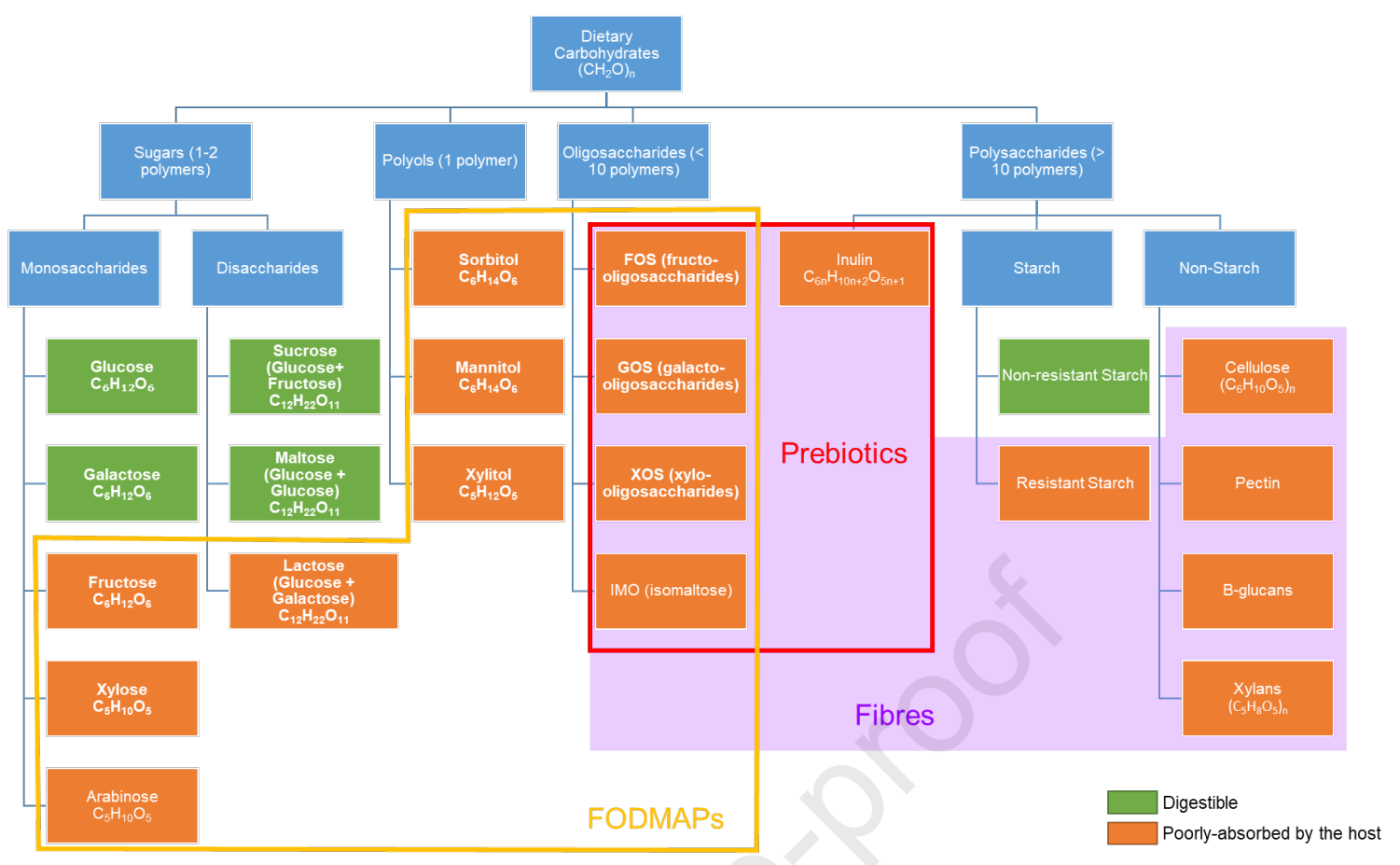




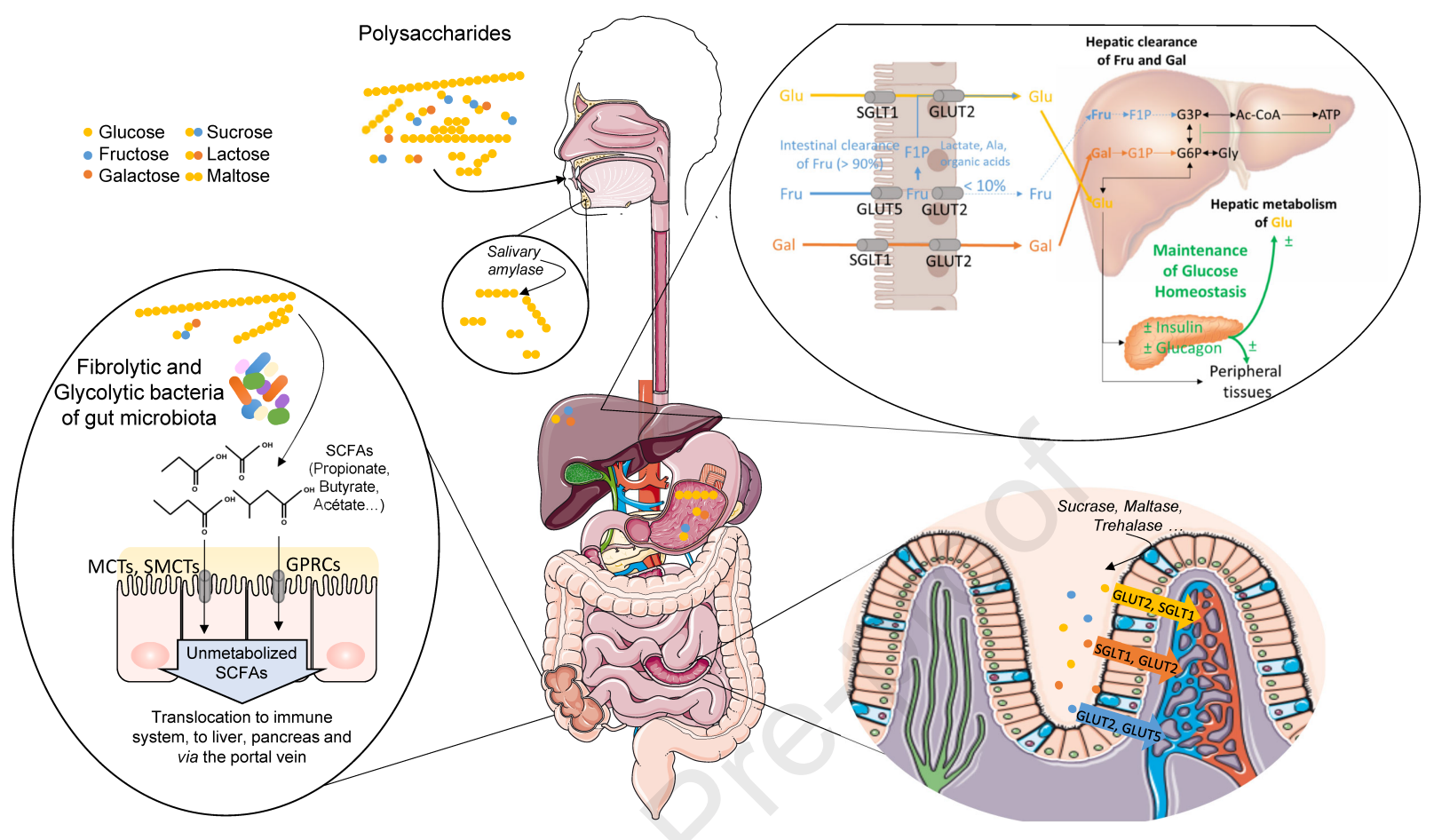




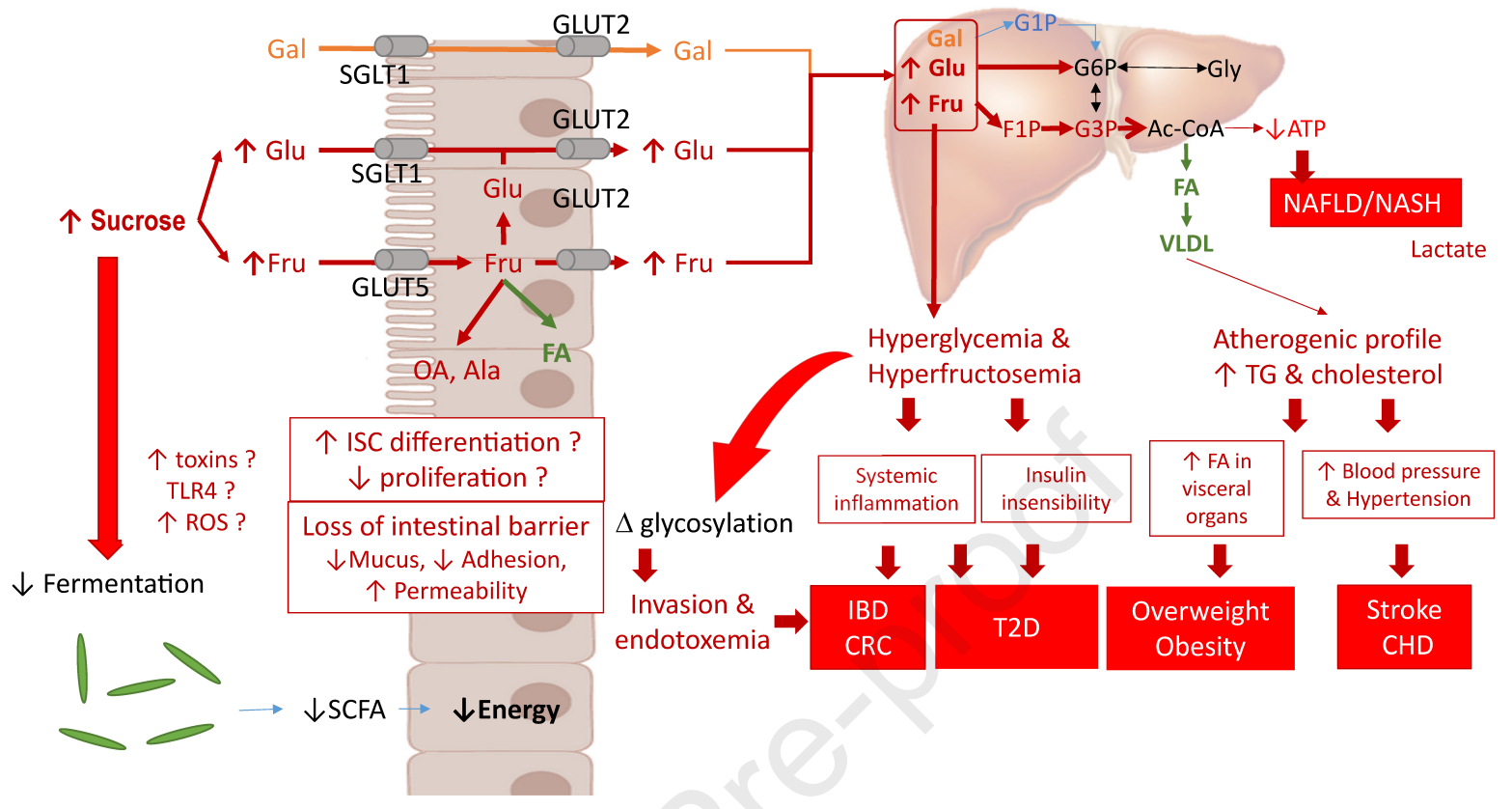




\section{Supplementary Informations Sugars and Gastrointestinal Health}

\section{LITERATURE SEARCH STRATEGY}

Relevant studies published up to July 2021 were searched through PubMed, Medline, Scopus and Google Scholar to identify all studies assessing the influence of dietary sugar consumption on the intestine. The following MeSH terms alone or combined with the Boolean operators 'and' or 'or' were used: 'sugar', 'sucrose', 'carbohydrates', 'ultraprocessed food', 'Western diet', 'dietary patterns', 'metabolism', 'colitis', 'gastrointestinal diseases', 'inflammatory bowel disease', and 'colorectal cancer'.

\section{In vitro evidence}

In vitro evidence suggests that processed simple sugars reduce white blood cell phagocytosis and possibly increase inflammatory cytokine markers in the blood ${ }^{1}$. Using Caco- 2 cells (intestinal epithelial cells from human colon), Thaiss et al. showed that high glucose exposition drives a global reprogramming of the epithelial cell transcriptome, and modifies the morphology of the cell-cell junctions leading to an abnormal influx of immune-stimulatory microbial products ${ }^{2}$. Interestingly, high fructose concentration affects the composition of $\mathrm{N}$ Glycans bound to membrane-associated glycoproteins present on the surface of Caco-2 cells ${ }^{3}$. These changes were associated with an increased invasion of bacteria, suggesting a preference for the types of cells they infect depending on the host glycome (intestinal epithelial cell surface glycans comprising the outermost layer of all eukaryotic cells $)^{4}$.

\section{Animal studies}

Sweetness is the preferred taste of humans and many animals, likely because sugars are a primary source of energy and rather rare in nature ${ }^{5}$. Many nutrients can influence gut homeostasis; while it is well known that chronic intake of high-fat diets differentially affect glucose tolerance in mice ${ }^{6,7}$. Most studies use diets enriched with fats and sugars or only with fats (Table S1). In vivo studies reported that fatty and sugary western diets promote intestinal inflammation because they alter the intestinal barrier (e.g. decreased mucus secretion), by increasing intestinal permeability and infection susceptibility, decreasing SCFA production by the microbiota and inducing dysbiosis ${ }^{8,9}$.

This inflammation results from an increase of natural killer NK T cells, a decrease of regulatory T cells (Treg) and a disequilibrium of dendritic cells. It correlates with the modulation of the expression of inflammatory proteins, exacerbating disease severity in colitis context ${ }^{8,10-16}$. 
Also, chronic low-grade inflammation has been linked to the overconsumption of Advanced Glycation End-Products (AGEs e.g. proteins or lipids glycated as a result of exposure to sugars) which lead to an increase in local and systemic pro-inflammatory biomarkers in humans and animal models ${ }^{17}$.

Nevertheless, if numerous studies describe the impact of a high fat diet on intestinal homeostasis, only a few were dedicated to sugar's specific implications ${ }^{18,19}$.

High sugar intake might disturb intestine homeostasis with several other manners. Firstly, the consumption of sugar-enriched diet might alter the architecture of the intestinal mucosa. High sugar diet promotes Intestinal Stem Cells differentiation into absorptive enterocytes and secretive enteroendocrine cells in Drosophila, caused the gut to become thinner, and produce high levels of ROS in the gut ${ }^{20}$. For example, fructose reduces mucus thickness in the colon and defensin secretion ${ }^{21}$. Recent studies demonstrated that dietary fructose worsens colitis in mice by altering the composition, localization, and metabolism of gut microbiota through mechanisms involving GLUT5 expression (fructose transporter) ${ }^{22,23}$.

In contrast, fibres consumption seems to protect from inflammation ${ }^{24}$. In both microbiotadependant and independent manner, pectin attenuates experimental colitis in mice ${ }^{25}$. Indeed, fibres deficiency reduces the epithelial cell proliferation ${ }^{26,27}$.

Secondly, high sugar intake might dysregulate essential pathways (appetite regulation, circadian rhythms...) in the intestinal mucosa ${ }^{28}$. Conversely L-arabinose (a monosaccharide extracted from plants or fibres) has been reported to inhibit colitis by modulating gut microbiota in mice ${ }^{29}$. Finally, it should be noticed that sugar impact on the intestine might differ according to the physiological conditions. In mice, bovine milk oligosaccharides supplementation reversed the western-diet induced increase in para- and transcellular flux, counter-balancing the dysbiosis and attenuated inflammation in the large intestine ${ }^{30}$. In mouse models of intestinal tumorigenesis, High Fructose Corn Syrup facilitates tumor growth ${ }^{31}$. In fact, luminal fructose absorption and utilization is more efficient in tumor cells than adjacent cells, and the excessive synthesis of Fructose-1-Phosphate leads to an acute drop of cytosolic ATP and subsequently enhances glucose metabolism in order to restore the ATP stores $^{32}$. It also activates fatty acids and eicosanoids syntheses that could contribute to tumorigenesis.

\section{Gut Microbiota}

Diet is a main modulator of the gut microbiota and is implicated in many diseases. Importantly, diet rapidly and reproducibly alters the human gut microbiome ${ }^{33}$. The evaluation of specific high-sugar diets is difficult because it often correlates with low fiber and high fat intake. Each 
type of nutrient seemingly can have cumulative effects (sucrose + high fat or fructose + high fat $)^{34}$. Dietary additives endemic to Western human populations can impact gut colonization by the microbiota independently of their ability to serve as nutrients ${ }^{35}$. Considering total carbohydrates, the lack of fermentable fibers leads to a shift toward an enrichment in mucindegrading bacteria that use the mucus layer as a source of nutrients ${ }^{26}$.

In both animals and humans, by changing the suite and amounts of sugars and sweeteners consumed, we create a novel gut environment that alters our microbial community, changes microbial metabolism and excreted metabolites, and selects for novel microbial strains (Table S1 ${ }^{36}$. Moreover, early-life sugar consumption significantly has been found to alter the gut microbiome independently of obesity and total caloric intake in a rodent model ${ }^{37}$.

High glucose and high fructose-fed mice lose gut microbial diversity (characterized by a reduced proportion of Bacteroidetes and a markedly increased proportion of Proteobacteria) ${ }^{38}$. Dietary sugars that escape absorption by the host intestine and reach the microbiota also regulate gut colonization by beneficial microbes ${ }^{35}$. High-sucrose diets (containing $70 \%$ of the kilocalories from carbohydrates, mainly in the form of sucrose) have previously been shown to elevate Clostridiales (a class of Firmicutes) and reduce Bacteroidales (an order of the phylum Bacteroidetes) abundance in adult rodents ${ }^{39}$. Dietary fructose intake was negatively associated with the abundance of the bacterial species Eubacterium eligens. It is known that E. eligens, along with other members of the phylum Firmicutes, have fewer polysaccharide-degrading enzymes than members of the phylum Bacteroidetes. Dietary fructose consumption is negatively associated with microbes belonging to the genus Streptococcus, including the species Streptococcus thermophilus. This bacterium has been shown to ferment lactose and sucrose and can also metabolize the monosaccharide fructose ${ }^{40}$. Recently, a study highlighted the importance of intestinal symbiosis to prevent chronic inflammation and the fact that the intestinal microbiota should always be studied from an ecosystem perspective instead of focusing on select bacterial species whose relative abundance correlates with the inflammatory level ${ }^{41}$.

Altogether, these data suggest that sugar promotes considerable differences in the gut microbiota at all taxonomic levels, with no apparent effect of the glucose-to-fructose ratio $^{37}$, and modulates microbes and metabolites influencing lipid accumulation ${ }^{42}$.

\section{REFERENCES}


1. Sørensen LB, Raben A, Stender S, et al. Effect of sucrose on inflammatory markers in overweight humans. Am J Clin Nutr 2005;82:421-427.

2. Thaiss CA, Levy M, Grosheva I, et al. Hyperglycemia drives intestinal barrier dysfunction and risk for enteric infection. Science 2018;359:1376-1383.

3. Park D, Xu G, Barboza M, et al. Enterocyte glycosylation is responsive to changes in extracellular conditions: implications for membrane functions. Glycobiology 2017;27:847-860.

4. Park D, Arabyan N, Williams CC, et al. Salmonella Typhimurium Enzymatically Landscapes the Host Intestinal Epithelial Cell (IEC) Surface Glycome to Increase Invasion. Mol Cell Proteomics MCP 2016;15:3653-3664.

5. von Molitor E, Riedel K, Krohn M, et al. Sweet Taste Is Complex: Signaling Cascades and Circuits Involved in Sweet Sensation. Front Hum Neurosci 2021;15:667709.

6. Sumiyoshi M, Sakanaka M, Kimura Y. Chronic Intake of High-Fat and High-Sucrose Diets Differentially Affects Glucose Intolerance in Mice. J Nutr 2006;136:582-587.

7. Sellmann C, Priebs J, Landmann M, et al. Diets rich in fructose, fat or fructose and fat alter intestinal barrier function and lead to the development of nonalcoholic fatty liver disease over time. J Nutr Biochem 2015;26:1183-1192.

8. Martinez-Medina M, Denizot J, Dreux N, et al. Western diet induces dysbiosis with increased $\mathrm{E}$ coli in CEABAC10 mice, alters host barrier function favouring AIEC colonisation. Gut 2014;63:116-124.

9. Rohr MW, Narasimhulu CA, Rudeski-Rohr TA, et al. Negative Effects of a High-Fat Diet on Intestinal Permeability: A Review. Adv Nutr Bethesda Md July 2019.

10. Cheng L, Jin H, Qiang Y, et al. High fat diet exacerbates dextran sulfate sodium induced colitis through disturbing mucosal dendritic cell homeostasis. Int Immunopharmacol 2016;40:1-10.

11. Devkota S, Wang Y, Musch MW, et al. Dietary-fat-induced taurocholic acid promotes pathobiont expansion and colitis in Il10 -/- mice. Nature 2012;487:104-108.

12. Liu B, Zhang $\mathrm{Y}$, Wang R, et al. Western diet feeding influences gut microbiota profiles in apoE knockout mice. Lipids Health Dis 2018;17.

13. Liu F, Wang X, Shi H, et al. Polymannuronic acid ameliorated obesity and inflammation associated with a high-fat and high-sucrose diet by modulating the gut microbiome in a murine model. Br J Nutr 2017;117:1332-1342.

14. Ma X, Torbenson M, Hamad ARA, et al. High-fat diet modulates non-CD1d-restricted natural killer $\mathrm{T}$ cells and regulatory $\mathrm{T}$ cells in mouse colon and exacerbates experimental colitis: High-fat diet and colonic inflammation. Clin Exp Immunol 2007;151:130-138.

15. Turnbaugh PJ, Bäckhed F, Fulton L, et al. Diet-Induced Obesity Is Linked to Marked but Reversible Alterations in the Mouse Distal Gut Microbiome. Cell Host Microbe 2008;3:213-223. 
16. Zeeni N, Dagher-Hamalian C, Dimassi H, et al. Cafeteria diet-fed mice is a pertinent model of obesity-induced organ damage: a potential role of inflammation. Inflamm Res 2015;64:501-512.

17. Nogueira Silva Lima MT, Howsam M, Anton PM, et al. Effect of Advanced Glycation End-Products and Excessive Calorie Intake on Diet-Induced Chronic Low-Grade Inflammation Biomarkers in Murine Models. Nutrients 2021;13:3091.

18. Laffin M, Fedorak R, Zalasky A, et al. A high-sugar diet rapidly enhances susceptibility to colitis via depletion of luminal short-chain fatty acids in mice. Sci Rep 2019;9.

19. Khan S, Waliullah S, Godfrey V, et al. Dietary simple sugars alter microbial ecology in the gut and promote colitis in mice. Sci Transl Med 2020;12:eaay6218.

20. Zhang X, Jin Q, Jin LH. High sugar diet disrupts gut homeostasis though JNK and STAT pathways in Drosophila. Biochem Biophys Res Commun 2017;487:910-916.

21. Volynets V, Louis S, Pretz D, et al. Intestinal Barrier Function and the Gut Microbiome Are Differentially Affected in Mice Fed a Western-Style Diet or Drinking Water Supplemented with Fructose. J Nutr 2017;147:770-780.

22. Montrose DC, Nishiguchi R, Basu S, et al. Dietary Fructose Alters the Composition, Localization, and Metabolism of Gut Microbiota in Association With Worsening Colitis. Cell Mol Gastroenterol Hepatol 2021;11:525-550.

23. Basu S, Liu C, Zhou XK, et al. GLUT5 is a determinant of dietary fructose-mediated exacerbation of experimental colitis. Am J Physiol Gastrointest Liver Physiol 2021;321:G232-G242.

24. Llewellyn SR, Britton GJ, Contijoch EJ, et al. Interactions Between Diet and the Intestinal Microbiota Alter Intestinal Permeability and Colitis Severity in Mice. Gastroenterology 2018;154:1037-1046.e2.

25. Ishisono K, Mano T, Yabe T, et al. Dietary Fiber Pectin Ameliorates Experimental Colitis in a Neutral Sugar Side Chain-Dependent Manner. Front Immunol 2019;10:2979.

26. Etienne-Mesmin L, Chassaing B, Desvaux M, et al. Experimental models to study intestinal microbes-mucus interactions in health and disease. FEMS Microbiol Rev 2019;43:457-489.

27. Chassaing B, Miles-Brown J, Pellizzon M, et al. Lack of soluble fiber drives diet-induced adiposity in mice. Am J Physiol Gastrointest Liver Physiol 2015;309:G528-541.

28. Rippe JM, Angelopoulos TJ. Sugars and Health Controversies: What Does the Science Say? Adv Nutr 2015;6:493S-503S.

29. Li Y, Pan H, Liu J, et al. L-Arabinose Inhibits Colitis by Modulating Gut Microbiota in Mice. J Agric Food Chem 2019;67:13299-13306.

30. Boudry G, Hamilton MK, Chichlowski M, et al. Bovine milk oligosaccharides decrease gut permeability and improve inflammation and microbial dysbiosis in diet-induced obese mice. J Dairy Sci 2017;100:2471-2481. 
31. Goncalves MD, Lu C, Tutnauer J, et al. High-fructose corn syrup enhances intestinal tumor growth in mice. Science 2019;363:1345-1349.

32. Nakagawa T, Lanaspa MA, Millan IS, et al. Fructose contributes to the Warburg effect for cancer growth. Cancer Metab 2020;8:16.

33. David LA, Maurice CF, Carmody RN, et al. Diet rapidly and reproducibly alters the human gut microbiome. Nature 2014;505:559-563.

34. Rosas-Villegas A, Sánchez-Tapia M, Avila-Nava A, et al. Differential Effect of Sucrose and Fructose in Combination with a High Fat Diet on Intestinal Microbiota and Kidney Oxidative Stress. Nutrients 2017;9:393.

35. Townsend GE, Han W, Schwalm ND, et al. Dietary sugar silences a colonization factor in a mammalian gut symbiont. Proc Natl Acad Sci 2019;116:233-238.

36. Di Rienzi SC, Britton RA. Adaptation of the Gut Microbiota to Modern Dietary Sugars and Sweeteners. Adv Nutr 2020;11:616-629.

37. Noble EE, Hsu TM, Jones RB, et al. Early-Life Sugar Consumption Affects the Rat Microbiome Independently of Obesity. J Nutr 2017;147:20-28.

38. Do MH, Lee E, Oh M-J, et al. High-Glucose or -Fructose Diet Cause Changes of the Gut Microbiota and Metabolic Disorders in Mice without Body Weight Change. Nutrients 2018;10.

39. Magnusson KR, Hauck L, Jeffrey BM, et al. Relationships between diet-related changes in the gut microbiome and cognitive flexibility. Neuroscience 2015;300:128-140.

40. Jones RB, Alderete TL, Kim JS, et al. High intake of dietary fructose in overweight/obese teenagers associated with depletion of Eubacterium and Streptococcus in gut microbiome. Gut Microbes April 2019:1-8.

41. Barnich N, Chassaing B. When Pathobiont-Carbohydrate Interaction Turns Bittersweet! Cell Mol Gastroenterol Hepatol September 2021.

42. Shan K, Qu H, Zhou K, et al. Distinct Gut Microbiota Induced by Different Fat-to-SugarRatio High-Energy Diets Share Similar Pro-obesity Genetic and Metabolite Profiles in Prediabetic Mice. mSystems 2019;4. 
Table S1: Summary of recent dietary studies where carbohydrates are linked to gut microbiota modifications in mice. - depeletion + presence $\downarrow$ decrease $\uparrow$ increase

\begin{tabular}{|c|c|c|c|c|c|c|}
\hline \multirow[t]{2}{*}{ Ref } & \multirow{2}{*}{$\begin{array}{l}\text { Diet / } \\
\text { Model }\end{array}$} & \multicolumn{5}{|c|}{ Described } \\
\hline & & Phyla & Order & Family & Genus (specie) & \\
\hline \multirow{4}{*}{$\begin{array}{l}\text { Arnone et al. } \\
2021^{112}\end{array}$} & \multirow{4}{*}{$\begin{array}{l}\text { High-fat high-sucrose (HFHS) } \\
\text { diet ( } 30 \% \text { sucrose, } 25 \% \text { fat) } \\
\text { 8-week-old male C57BL/ } \\
6 \mathrm{~J} \text { mice }\end{array}$} & Firmicutes & Clostridiales & & & $\downarrow$ \\
\hline & & Firmicutes & Clostridiales & Lachnospiraceae & & $\uparrow$ \\
\hline & & & & & & \\
\hline & & Bacteroidetes & Bacteroidales & Porphyromonadaceae & Barnesiella & $\downarrow$ \\
\hline \multirow[t]{7}{*}{ Li et al. $2021^{113}$} & \multirow{7}{*}{$\begin{array}{l}\text { High-fat high-sucrose (HFHS) } \\
\text { diet ( } 20 \% \text { sucrose, } 20 \% \text { fat) } \\
\text { 8-week-old male C57BL/ } \\
6 \mathrm{~J} \text { mice }\end{array}$} & Firmicutes & & & & $\uparrow$ \\
\hline & & & & & & \\
\hline & & Bacteroidetes & & & & $\downarrow$ \\
\hline & & Verrucomicrobia & & & & $\downarrow$ \\
\hline & & Proteobaceria & & & & $\downarrow$ \\
\hline & & Actinobacteria & & & & $\uparrow$ \\
\hline & & Patescibacteria & & & & $\uparrow$ \\
\hline \multirow[t]{4}{*}{$\begin{array}{l}\text { Khan et al. } 2020 \\
114\end{array}$} & \multirow[t]{4}{*}{$\begin{array}{l}10 \% \text { glucose or fructose or } \\
\text { sucrose in drinking water during } 7 \\
\text { days } \\
\text { Wild-type C57B16/J }\end{array}$} & Bacteroidetes & $\begin{array}{l}\text { Bacteroidales } \\
\text { Bacteroidales } \\
\text { Bacteroidales } \\
\text { Bacteroidales } \\
\text { Marinilabiliales } \\
\text { Bacteroidales }\end{array}$ & $\begin{array}{l}\text { Tannerellaceae } \\
\text { Odoribacteraceae } \\
\text { Muribaculaceae } \\
\text { Bacteroidaceae } \\
\text { Marinilabiliaceae } \\
\text { Rikenellaceae }\end{array}$ & & $\begin{array}{l}\uparrow \\
\downarrow \\
\uparrow \\
\uparrow \\
\uparrow \\
\downarrow\end{array}$ \\
\hline & & Verrucomicrobia & Verrucomicrobiales & Akkermansiaceae & & $\uparrow$ \\
\hline & & Proteobacteria & $\begin{array}{l}\text { Desulfovibrionales } \\
\text { Sutterellaceae }\end{array}$ & $\begin{array}{l}\text { Desulfovibrionaceae } \\
\text { Sutterellaceae }\end{array}$ & & $\begin{array}{l}\downarrow \\
\uparrow\end{array}$ \\
\hline & & Firmicutes & $\begin{array}{l}\text { Lactobacillales } \\
\text { Eubacteriales } \\
\text { Erysipelotrichales } \\
\text { Eubacteriales } \\
\end{array}$ & $\begin{array}{l}\text { Lactobacillaceae } \\
\text { Hungateiclostridiaceae } \\
\text { Erysipelotrichaceae } \\
\text { Ruminococcaceae }\end{array}$ & & $\begin{array}{l}\downarrow \\
\downarrow \\
\downarrow \\
\downarrow\end{array}$ \\
\hline
\end{tabular}




\begin{tabular}{|c|c|c|c|c|c|c|}
\hline & & & & Lachnospiraceae & & $\downarrow$ \\
\hline \multirow{5}{*}{$\begin{array}{l}\text { Laffin et al. } \\
2019115\end{array}$} & \multirow{5}{*}{$\begin{array}{l}\text { High sucrose diet ( } 55 \% \text { sucrose) } \\
\text { during } 2 \text { days } \\
\text { Wild-type mice on a } 129 \mathrm{~S} 1 / \text { SvimJ } \\
\text { background were female mice } 6 \text { - } \\
8 \text { wks }\end{array}$} & Proteobacteria & & & & $\downarrow$ \\
\hline & & Bacteroidetes & Bacteroidales & $\begin{array}{l}\text { Prevotellaceae } \\
\text { Porphyromonadaceae }\end{array}$ & & $\begin{array}{l}\downarrow \\
\uparrow\end{array}$ \\
\hline & & Tenericutes & Anaeroplasmatales & Anaeroplasmataceae & & $\downarrow$ \\
\hline & & Firmicutes & Eubacteriales & Lachnospiraceae & & $\downarrow$ \\
\hline & & Verrucomicrobia & Verrucomicrobiales & Verrucomicrobiaceae & & $\uparrow$ \\
\hline \multirow[t]{4}{*}{$\begin{array}{l}\text { Magnusson et } \\
\text { al. } 2015^{72}\end{array}$} & \multirow[t]{4}{*}{$\begin{array}{l}\text { High sucrose diet in mice for } 2 \\
\text { weeks }\end{array}$} & Bacteroidetes & $\begin{array}{l}\text { Bacteroidales (than both } \\
\text { normal and high fat diet } \\
\text { mice) }\end{array}$ & $\begin{array}{l}\text { Porphyromonadaceae } \\
\text { Porphyromonadaceae } \\
\text { Rikenellaceae }\end{array}$ & $\begin{array}{l}\text { Barnesiella } \\
\text { Other } \\
\text { Alistipes }\end{array}$ & $\downarrow$ \\
\hline & & \multirow[t]{3}{*}{ Firmicutes } & $\begin{array}{l}\text { Lactobacillales (than both } \\
\text { normal and high fat diet } \\
\text { mice) }\end{array}$ & $\begin{array}{l}\text { Enterococcaceae } \\
\text { Lactobacillaceae } \\
\text { Streptococcaceae }\end{array}$ & $\begin{array}{l}\text { Enterococcus }+ \\
\text { Lactobacillus } \uparrow \\
\text { Lactococcus } \uparrow\end{array}$ & $\uparrow$ \\
\hline & & & Clostridiales & $\begin{array}{l}\text { Lachnospiraceae } \\
\text { Ruminococcaceae }\end{array}$ & $\begin{array}{l}\text { Other } \uparrow \\
\text { Other } \uparrow\end{array}$ & $\uparrow$ \\
\hline & & & $\begin{array}{l}\text { Tenericutes - } \\
\text { Mollicutes - } \\
\text { Anaeroplasmatales - }\end{array}$ & & & - \\
\hline \multirow{12}{*}{$\begin{array}{l}\text { Martinez- } \\
\text { Medina et al. } \\
2014\end{array}$} & \multirow{12}{*}{$\begin{array}{l}\text { High fat High sucrose diet in mice } \\
\text { for } 12 \text { weeks }\end{array}$} & \multirow{4}{*}{ Firmicutes } & & & & $\downarrow$ \\
\hline & & & \multirow[t]{3}{*}{ Clostridiales } & \multirow[t]{2}{*}{ Ruminococcaceae } & $\begin{array}{l}\text { Ruminococcus } \\
\text { (gnavus and torques) }\end{array}$ & $\uparrow$ \\
\hline & & & & & $\begin{array}{l}\text { Faecalibacterium } \\
\text { (prausnitzii) }\end{array}$ & - \\
\hline & & & & Clostriaceae & $\begin{array}{l}\text { Clostridium } \\
\text { (coccoides) }\end{array}$ & - \\
\hline & & Actinobacteria & Bifidobacteriales & Bifidobacteriaceae & Bifidobacterium & - \\
\hline & & \multirow[t]{2}{*}{ Bacteroidetes } & & & & $\uparrow$ \\
\hline & & & Bacteroidales & Prevotellaceae & Prevotella & $\uparrow$ \\
\hline & & Proteobacteria & & & & $\uparrow$ \\
\hline & & Deferribacteres & & & & $\downarrow$ \\
\hline & & Spirochaetes & & & & $\downarrow$ \\
\hline & & Tenericutes & & & & $\downarrow$ \\
\hline & & Bacteroidetes & Bacteroidales & Prevotellaceae & Prevotella copri & $\downarrow$ \\
\hline
\end{tabular}




\begin{tabular}{|c|c|c|c|c|c|c|}
\hline \multirow{5}{*}{$\begin{array}{l}\text { Kovatcheva- } \\
\text { Datchary et al. } \\
2019116\end{array}$} & \multirow{5}{*}{$\begin{array}{l}\text { High sucrose zero fat diet ( } 62 \% \\
\text { sucrose) in Simplified Intestinal } \\
\text { Microbiota (ten sequenced strains } \\
\text { isolated from human gut) mice for } \\
2 \text { weeks }\end{array}$} & \multirow[t]{2}{*}{ Actinobacteria } & Bifidobacteriales & Bifidobacteriaceae & $\begin{array}{l}\text { Bifidobacterium } \\
\text { adolescentis }\end{array}$ & $\downarrow$ \\
\hline & & & Coriobacteriales & Coriobacteriaceae & $\begin{array}{l}\text { Collinsella } \\
\text { aerofaciens }\end{array}$ & $\downarrow$ \\
\hline & & \multirow[t]{2}{*}{ Firmicutes } & \multirow[t]{2}{*}{ Clostridiales } & Ruminococcaceae & $\begin{array}{l}\text { Ruminococcus } \\
\text { inulinivorans }\end{array}$ & $\downarrow$ \\
\hline & & & & Eubacteriaceae & Eubacterium hallii & $\uparrow$ \\
\hline & & Verrucomicrobia & Verrucomicrobiales & Akkermansiaceae & $\begin{array}{l}\text { Akkermansia } \\
\text { muciniphila }\end{array}$ & $\uparrow$ \\
\hline \multirow{7}{*}{$\begin{array}{l}\text { Rosas-Villegas } \\
\text { et al. } 2017^{67}\end{array}$} & \multirow{3}{*}{$\begin{array}{l}\text { High fat high sucrose in rats for } 4 \\
\text { months }\end{array}$} & Bacteroidetes & $\infty$ & & & $\downarrow$ \\
\hline & & Firmicutes & $\begin{array}{l}\text { Erysipelotrichales } \\
\text { Lactobacillales } \\
\text { Clostridiales } \\
\text { Clostridiales } \\
\text { Selenomonadales }\end{array}$ & $\begin{array}{l}\text { Erysipelotrichaceae } \\
\text { Lactobacillaceae } \\
\text { Eubacteriaceae } \\
\text { Lachnospiraceae } \\
\text { Acidaminococcaceae }\end{array}$ & $\begin{array}{l}\text { Turicibacter } \\
\text { P75- a5 } \\
\text { Lactobacillus } \\
\text { Eubacterium } \\
\text { Coprococcus } \\
\text { (C. eutactus) } \\
\text { Acidaminococcus }\end{array}$ & $\begin{array}{l}\downarrow \downarrow \\
\downarrow \downarrow \\
\uparrow \\
\downarrow \\
\downarrow\end{array}$ \\
\hline & & Proteobacteria & $\begin{array}{l}\text { Enterobacterales } \\
\text { Sphingomonadales } \\
\text { Desulfovibrionales } \\
\text { Pasteurellales }\end{array}$ & $\begin{array}{l}\text { Enterobacteriaceae } \\
\text { Sphingomonadaceae } \\
\text { Desulfovibrionaceae } \\
\text { Pasteurellaceae }\end{array}$ & $\begin{array}{l}\text { Klebsiella } \\
\text { Sphingomonas } \\
\text { Bilophila } \\
\text { Aggregatibacter }\end{array}$ & $\begin{array}{l}\downarrow \downarrow \\
\downarrow \downarrow \\
\downarrow \downarrow \\
\downarrow \downarrow\end{array}$ \\
\hline & \multirow{4}{*}{$\begin{array}{l}\text { High fat high fructose in rats for } 4 \\
\text { months }\end{array}$} & Bacteoidetes & & & & $\downarrow$ \\
\hline & & Firmicutes & $\begin{array}{l}\text { Erysipelotrichales } \\
\text { Lactobacillales } \\
\text { Clostridiales } \\
\text { Clostridiales } \\
\text { Selenomonadales }\end{array}$ & $\begin{array}{l}\text { Erysipelotrichaceae } \\
\text { Lactobacillaceae } \\
\text { Eubacteriaceae } \\
\text { Lachnospiraceae } \\
\text { Acidaminococcaceae }\end{array}$ & $\begin{array}{l}\text { Turicibacter } \\
\text { P75- a5 } \\
\text { Lactobacillus } \\
\text { (L. reuteri) } \\
\text { Eubacterium } \\
\text { Coprococcus } \\
\text { (C.eutactus) } \\
\text { Acidaminococcus }\end{array}$ & $\begin{array}{l}\downarrow \\
\downarrow \\
\uparrow\end{array}$ \\
\hline & & Proteobacteria & $\begin{array}{l}\text { Enterobacterales } \\
\text { Sphingomonadales } \\
\text { Desulfovibrionales } \\
\text { Pasteurellales }\end{array}$ & $\begin{array}{l}\text { Enterobacteriaceae } \\
\text { Sphingomonadaceae } \\
\text { Desulfovibrionaceae } \\
\text { Pasteurellaceae }\end{array}$ & $\begin{array}{l}\text { Klebsiella } \\
\text { Sphingomonas } \\
\text { Bilophila } \\
\text { Aggregatibacter }\end{array}$ & $\begin{array}{l}\downarrow \\
\downarrow \\
\downarrow \\
\downarrow\end{array}$ \\
\hline & & Bacteroidetes & Bacteroidales & Bacteroidaceae & Bacteroides & $\downarrow$ \\
\hline
\end{tabular}




\begin{tabular}{|c|c|c|c|c|c|c|}
\hline \multirow{6}{*}{$\begin{array}{l}\text { Shan et al. } 2019 \\
75\end{array}$} & \multirow{6}{*}{$\begin{array}{l}\text { High fat high sucrose diet in mice } \\
\text { for } 120 \text { days }\end{array}$} & \multirow[t]{3}{*}{ Firmicutes } & Clostridiales & Lachnospiraceae & Coprococcus & $\uparrow$ \\
\hline & & & Erysipelotrichales & Erysipelotrichidae & Allobaculum & $\uparrow$ \\
\hline & & & Lactobacillales & Lactobacillaceae & Lactobacillus & $\downarrow \downarrow$ \\
\hline & & Verrucomicrobia & Verrucomicrobiales & Akkermansiaceae & Akkermansia & $\uparrow \uparrow$ \\
\hline & & \multirow[t]{2}{*}{ Actinobacteria } & Coriobacteriales & Coriobacteriaceae & Adlercreutzia & $\downarrow \downarrow$ \\
\hline & & & Bifidobacteriales & Bifidobacteriaceae & Bifidobacterium & $\uparrow$ \\
\hline \multirow{6}{*}{$\begin{array}{l}\text { Volynets et al. } \\
2017\end{array}$} & \multirow{6}{*}{$\begin{array}{l}\text { High fat high fructose diet or } \\
\text { control + fructose in mice for } 12 \\
\text { weeks }\end{array}$} & \multirow[t]{2}{*}{ Bacteroidetes } & & & & $\downarrow$ \\
\hline & & & Bacteroidales & Bacteroidaceae & Parabacteroides & $\downarrow$ \\
\hline & & \multirow[t]{2}{*}{ Firmicutes } & & & & $\uparrow$ \\
\hline & & & Clostriales & Peptostreptococcaceae & & $\downarrow$ \\
\hline & & Proteobacteria & Burkholderiales & & & $\uparrow$ \\
\hline & & Actinobacteria & Bifidobacteriales & Bifidobacteriaceae & Bifidobacterium & $\uparrow \uparrow$ \\
\hline \multirow{6}{*}{$\begin{array}{l}\text { Meng et al. } 2019 \\
117\end{array}$} & \multirow{6}{*}{$\begin{array}{l}\text { High sugar diet in rats for } 12 \\
\text { weeks }\end{array}$} & Proteobacteria & & & & $\uparrow$ \\
\hline & & Actinobacteria & 2 & & & $\uparrow$ \\
\hline & & \multirow[t]{3}{*}{ Firmicutes } & \multirow{2}{*}{ Lactobacillales } & Lactobacillaceae & Lactobacillus & $\uparrow$ \\
\hline & & & & Streptococcaceae & Streptococcus & $\uparrow$ \\
\hline & & & Erysipelotrichales & Erysipelotrichidae & Allobaculum & $\uparrow$ \\
\hline & & Bacteroidetes & & & & $\downarrow$ \\
\hline \multirow{6}{*}{ Agus et al. 2016} & \multirow{6}{*}{$\begin{array}{l}\text { High fat high sugars diet in mice } \\
\text { for } 18 \text { weeks }\end{array}$} & Bacteroidetes & Bacteroidales & Bacteroidaceae & Bacteroides & $\uparrow$ \\
\hline & & \multirow{2}{*}{ Firmicutes } & & & & $\downarrow$ \\
\hline & & & Clostridiales & Lachnospiraceae & $\begin{array}{l}\text { Ruminococcus } \\
\text { torques }\end{array}$ & $\uparrow$ \\
\hline & & Proteobacteria & Deferribacterales & Deferribacteraceae & & $\uparrow$ \\
\hline & & Deferribacteres & & & & $\uparrow \uparrow$ \\
\hline & & Actinobacteria & & & & $\uparrow$ \\
\hline \multirow{9}{*}{$\begin{array}{l}\text { Rahman et al. } \\
2016\end{array}$} & \multirow{9}{*}{$\begin{array}{l}\text { High fat high fructose and } \\
\text { cholesterol diet in mice for } 8 \\
\text { weeks }\end{array}$} & \multirow[t]{3}{*}{ Bacteriodetes } & & & & $\downarrow$ \\
\hline & & & Bacteroidales & Bacteoidaceae & Bacteroides & $\uparrow$ \\
\hline & & & Bacteroidales & Prevotellaceae & Prevotella & $\downarrow$ \\
\hline & & Cyanobacteria & & & & $\downarrow$ \\
\hline & & \multirow[t]{2}{*}{ Proteobacteria } & & & & $\uparrow$ \\
\hline & & & Desulfovibrionales & Desulfovibrionaceae & & $\uparrow$ \\
\hline & & \multirow[t]{2}{*}{ Firmicutes } & & & & $\uparrow$ \\
\hline & & & Clostridiales & Ruminococcaceae & Ruminococcus & $\downarrow$ \\
\hline & & Tenericutes & Mollicutes & Mycoplasmataceae & & $\downarrow \downarrow$ \\
\hline
\end{tabular}


